\title{
Defining Drought in the Context of Stream Health
}

\author{
Elaheh Esfahanian ${ }^{\text {a }}$, A. Pouyan Nejadhashemi a, ${ }^{\text {, }}$, Mohammad Abouali ${ }^{\text {a }}$, Fariborz Daneshvar ${ }^{\text {a }}$, Alireza \\ Ameli Renani ${ }^{\mathrm{b}}$, Matthew R. Herman ${ }^{\mathrm{a}}$, Ying Tang ${ }^{\mathrm{c}}$ \\ ${ }^{a}$ Department of Biosystems and Agricultural Engineering, Michigan State University, East Lansing, MI 48824, USA \\ ${ }^{\mathrm{b}}$ Department of Computer Science and Engineering, Michigan State University, East Lansing, MI 48824, USA. \\ ${ }^{\mathrm{c}}$ Department of Geography, Michigan State University, East Lansing, MI, USA. \\ * Corresponding Author. Tel.: (517) 432-7653. Email address: pouyan@msu.edu (A. Pouyan
}

Nejadhashemi)

\begin{abstract}
Droughts affect many sectors, such as agriculture, economic, social, human health, and ecosystems. Many drought indices have been developed; yet, none of them quantifies the impacts of drought on stream health. The purpose of this study is to define a new drought index capable of assessing fish vulnerability. To accomplish this, a hydrological model, called the Soil and Water Assessment Tool (SWAT), and the Regional-scale Habitat Suitability model were integrated in order to understand the state of drought within 13,831 stream segments within the Saginaw Bay Watershed. The ReliefF algorithm was used as the variable selection method, and partial least squared regression was used to develop two sets of predictor models capable of determining current and future drought severities. Forty-seven different climate scenarios were used to investigate drought model predictability of future climate scenarios. The results indicated that the best drought model has a high capability for predicting future drought conditions with $R^{2}$ values ranging from 0.86 to 0.89 . In general, the majority of reaches (94\%) will experience higher drought probability under future climate scenarios compared to current conditions. The
\end{abstract}


procedure introduced in this study is transferable to other watersheds with regional standards for environmental flow to measure the impacts of drought on stream health.

Keywords: Great Lakes; Stream Health; Climate Change; Risk; SWAT

\section{Introduction}

Droughts are temporary events that can occur almost in all climatic zones and are related to the reduction in received precipitation during a period of time (Wilhite et al., 2014; Mishra and Singh, 2010). Drought ultimately impacts both surface and groundwater resources (Mishra and Singh, 2010). Droughts rank first, among all the natural hazards that affect the human well-being (Wilhite, 2000b; Mishra and Singh, 2010); and they are the most costly natural disasters of the world (Wilhite, 2000b; Keyantash and Dracup, 2002). Globally, droughts cause an average of $\$ 6$ to $\$ 8$ billion in damages annually (Wilhite, 2000b; Keyantash and Dracup, 2002). Therefore, it is important to predict the timing and extent of droughts to help with development of mitigation strategies.

Drought is typically classified as either meteorological, hydrological, agricultural, or ecological drought (Wilhite and Glantz, 1985; American Meteorological Society, 1997; McMahon and Finlayson, 2003; Sheffield and Wood, 2011). Moreover, for each type of drought several drought indices have been developed. Meteorological droughts occur when there is a significant deviation from the mean precipitation in a region (Mishra and Singh, 2010; Sheffield and Wood, 2011). The Standardized Precipitation Index (McKee et al., 1993, 1995; Mishra and Desai, 2005a, 2005b; Cancelliere et al., 2007; Mishra et al., 2007; Mishra and Singh, 2009) and Percent of Normal (Hayes, 2006; Sheffield and Wood, 2011; Zargar et al., 2011) are examples of commonly used meteorological drought indices. Hydrological droughts refer to a period of 
deficiency in the supply of water (both surface and subsurface water) (Panu and Sharma, 2002; Mishra and Singh, 2010; Sheffield and Wood, 2011). Streamflow, lake/reservoir levels, and groundwater levels are the parameters that are used to define hydrological drought (Mishra and Singh, 2010; Sheffield and Wood, 2011). Common hydrological drought indices are the Palmer Hydrological Drought Index (Palmer, 1965; Heim, 2000; Keyantash and Dracup, 2002; Mishra and Singh, 2010; Zargar et al., 2011), the Baseflow Index (The institute of Hydrology, 1980; Gustard et al., 1992; Zaidman et al., 2001; Tallaksen and van Lanen, 2004; Sheffield and Wood, 2011), and the Surface Water Supply Index (Shafer and Dezman,1982; Heim, 2002; Hayes, 2006; Mishra and Singh, 2010; Sheffield and Wood, 2011). Agricultural droughts are defined as a period of soil moisture deficiency, which reduces moisture supply for vegetation and crop yield (Panu and Sharma, 2002; Sheffield and Wood, 2011). This type of drought is driven by meteorological and hydrological droughts (Sheffield and Wood, 2011). Several drought indices have been used to study agricultural drought including the Palmer Drought Severity Index (Alley 1984; Rao and Padmanabham, 1984; Johnson and Kohne, 1993; Kim and Valdes, 2003; Dai et al., 2004; Özger et al., 2009) and the Crop Moisture Index (Palmer, 1968; Hayes, 2006; Mishra and Singh, 2010; Sheffield and Wood, 2011). These indices use a combination of hydrometeorological variables such as precipitation, soil moisture, and temperature to analyze agricultural drought (Mishra and Singh, 2010). Ecological drought indices measure the impacts of drought on ecosystems (Sheffield and Wood, 2011); yet, few indices have been developed to quantify these impacts. Examples include the Normalized Difference Vegetation Index that is generally used to monitor the health of a canopy (Rouse et al., 1974; Singh et al., 2003; Kogan, 2005) and Vegetation Condition Index (Kogan, 1995; Singh et al., 2003; Quiring and Ganesh, 2010; Wardlow et al., 2012). 
In general, a concept of drought that has received the least attention is ecohydrological aspects of drought that can be summarized as stream health. A healthy stream is an ecosystem that is flourishing, sustainable, resilient to stress, and maintains its societal values over time (Meyer, 1997). Many biological monitoring methods exist to measure the ecological conditions of stream systems. Among these methods, biological indicators are widely used for detecting the presence of point and non-point source pollutants, changes in physical habitat, and the effects of long-term disturbance events on ecosystems (Barbour et al., 1999; Nerbonne and Vondracek, 2001; Flinders et al., 2008). Fish are the most commonly used biological communities for water-quality assessments (Barbour et al., 1999; Flinders et al., 2008; Carlisle et al., 2013). Fish are sources of food for aquatic and terrestrial species, while being primary consumers of macroinvertebrates and algae (Carlisle et al., 2013). This links fish communities to other biotic characteristics of the ecosystem, which allows fish to be representative of the larger picture within the stream system. Furthermore, fish are relatively easy to collect and identify, provide long-term and regional impacts due to their mobility and lifespan, and their environmental requirements are well-known (Karr, 1981; Barbour et al., 1999; Carlisle et al., 2013). Additionally, fish assemblages cover a variety of trophic levels such as omnivores, herbivores, insectivores, planktivores, and piscivores, which provides an integrative view of stream environmental health (Karr, 1981; Barbour et al., 1999).

Flow is a key driver of stream ecological processes that affect aquatic organism performance, distribution, and abundance (Hart and Finelli, 1999; Bunn and Arithington, 2002). Alteration of flow regimes especially during dry seasons can significantly affect the ecosystem health (Koster et al., 2010; Hamaamin et al., 2013). Drought perturbs stream ecological conditions by altering native biological communities such as fish assemblages (Lake, 2003). Drought can cause 
reductions and alterations in fish populations and their structure by reducing spawning and recruitment (Lake, 2003). Therefore, it is important to quantify the impacts of drought on stream biota.

In this study, a new drought index is defined in the context of stream health. In general, the majority of drought indices are sensitive to the impacts of drought to human usages including drinking or crop production neglecting other aspects of environmental sustainability such as stream health. Therefore, this study is unique because it uses fish integrity as an indicator to define drought. By coupling the hydrologic model with a regional-scale habitat suitability model, the drought model will be developed capable of identifying drought zones for all streams within the study area. This allows targeting the streams that are more prone to degradation due to extreme climatological conditions allowing mitigation practices to be more effectively deployed.

\section{Materials and Methodology}

\subsection{Study area}

The study area for this study is the Saginaw Bay Watershed located in the east central region of Michigan's Lower Peninsula; with a total area of $16,122 \mathrm{~km}^{2}$, its final outlet drains into Lake Huron, Figure 1. Most of this area is agricultural and forest lands (37\% and 37\%, respectively), with the agricultural lands dominated by corn and soybean crops. The remaining lands are pasture $(9.5 \%)$, urban $(7.5 \%)$, wetlands $(8 \%)$, and water $(1 \%)$. The Saginaw Bay Watershed is Michigan's largest 6-digit hydrologic unit code (HUC 040802) and consists of six 8-digit HUC watersheds, the Tittabawassee (HUC 04080201), Pine (HUC 04080202), Shiawassee (HUC

04080203), Flint (HUC 04080204), Cass (HUC 04080205), and Saginaw (HUC 04080206). There are 13,831 stream segments within the Saginaw Bay Watershed with different 
sizes and temperatures; with the majority of streams being warm water streams (Einheuser et al., 2013). The Saginaw Bay Watershed has been designated as area of concern by the US Environmental Protection Agency due to fish consumption advisories caused by excessive agrochemical utilization and contaminated sediments (USEPA, 2013).

\subsection{Modeling process}

The goal of the modeling process is to predict drought zones based on stream health. In order to accomplish this goal, a multi-step modeling process was developed (Figure 2). First, the Soil and Water Assessment Tool, a hydrological model, was used to obtain daily streamflow data (19722012) for all stream segments in the Saginaw Bay Watershed. The daily streamflow data was used as an input into a regional-scale habitat suitability model in order to assess the impacts of flow fluctuation on fish assemblages. Next, the changes in fish assemblages were translated into drought zones. Knowing drought zones for each stream segment, it was hypothesized that a drought predictive model could be developed using physiographical and climatological variables. Selected variables were then used to accomplish two general goals: 1) develop a drought model capable of determining current drought severity (using ReliefF algorithm) and 2) develop a drought forecast model capable of predicting future drought severity (using time series variables). Finally, the partial least square regression was used to create drought predictive models using the previously selected variables.

\subsection{Soil and Water Assessment Tool}

In this study, the Soil and Water Assessment Tool (SWAT) was used to simulate daily streamflow data for 13,831 stream segments of the Saginaw Bay watershed. SWAT is a physically based, continuous time model developed by the US Department of Agriculture Agricultural Research Service (Gassman et al., 2007). In this spatially explicit model, a 
watershed is delineated into multiple subwatersheds, which are further segmented into hydrologic response units (HRUs) with homogenous land cover, soil, slope, and management practices. This model uses physiographical and climatological characteristics of a region to simulate streamflow, runoff, soil erosion, as well as nutrient, sediment, and pesticide loadings (Gassman et al., 2007; Neitsch et al., 2011).

Different sources were used to obtain the physiographical and climatological data needed to run SWAT model. The National Elevation Dataset (NED) of the US Geological Survey (USGS) with a spatial resolution of $10 \mathrm{~m}$ was used to represent the topography data of the region (NED, 2014). The Natural Resources Conservation Service (NRCS) Soil Survey Geographic (SSURGO) database was used to identify soil characteristics in the area of interest (NRCS, 2014a). The 2012 Cropland Data Layer (Figure 3) of the United States Department of Agriculture-National Agricultural Statistics Service (USDA-NASS) with a spatial resolution of $30 \mathrm{~m}$ was used to represent land use/land cover data (NASS, 2012). Climatological data were obtained from 16 precipitations and 13 temperature National Climatic Data Center (NCDC) stations. Daily precipitation and temperature data were obtained at these stations for the period of 1972 to 2012. In the SWAT model, the climatological data are assigned to each subbasin based on the proximity of the weather stations to the centroid of each subbasin (Golden et al., 2016).

\subsection{SWAT model calibration and validation}

The SWAT model was calibrated and validated against the observed daily streamflow data of nine USGS gauging stations (presented in the Supplementary Material, Figure S1) from 2001 to 2010. The first half of this period (2001 to 2005) was used for calibration and the second half (2006 to 2010) was used for validation. Three statistical variables were used to examine the quality of calibration and validation: Nash-Sutcliffe model efficiency coefficient (NSE), root- 
mean-squared error-observations standard deviation ratio (RSR), and percent bias (PBIAS). Passing criteria for these three variables are NSE $>0.5$, RSR $<0.7$, and PBIAS $< \pm 25$ on a monthly basis (Moriasi et al., 2007).

\subsection{Regional-scale Habitat Suitability Model}

The calibrated SWAT model was run from 1972 to 2012 in order to obtain the streamflow data needed for a regional-scale habitat suitability model. This model was created with the goal of introducing regional environmental flow standards for Michigan Rivers (Zorn et al., 2008). Environmental flow is defined as the quantity and quality of the water flow required to sustain freshwater ecosystems (Poff et al., 2010). Therefore, developing standards for environmental flow can protect aquatic ecosystem from adverse impacts. The regional-scale habitat suitability model predicts the effect of flow reduction on fish assemblages during summer months (July, August, and September) (Zorn et al., 2008; Hamilton and Seelbach, 2011). In Michigan, summer months are the period with the lowest flow for most streams and one of the most biologically stressful periods. In order to characterize this period, an index flow was developed. The index flow is the median of the daily flow values of the lowest summer month of the flow regime (Hamilton and Seelbach, 2011). Critical flow reduction will be calculated based on the percentage of index flow. In this model, about 40 fish species were used as stream health indicators. The fish data were obtained from fish surveys at 1,720 sites from 1980 to 2006 . Three habitat variables were used to define the optimal fish species habitat conditions. These variables were catchment area, July mean water temperature, and base flow yield. The fish species were divided into characteristic and thriving species. Characteristic species were defined as those species that have all three of their habitat variable scores within 1.5 standard deviations of the 
optimal values. And, thriving species were defined as those species that have all three of their habitat variable scores within 1 standard deviation of the optimal values (Zorn et al., 2008).

Zorn et al. (2008) classified Michigan rivers into 11 groups based on their catchment size (stream, small river, and large river) and water temperature (cold, cold-transitional, cool, and warm). The fish assemblage response curves for all 11 river classes were created to determine the effect of flow reduction on characteristic and thriving species. Each response graph (e.g. Figure 4) has two curves, one for thriving species and one for characteristic species response. Based on the Biological Condition Gradient concept (Davies and Jackson, 2006), the Groundwater Conservation Advisory Council recommended to divide the response curve into four risk zones, i.e. A, B, C, and D. The potential risk of flow reduction increases from zone A to zone $\mathrm{D}$, where zone A represents no risk to the fish population, zone $\mathrm{B}$ shows alert and attention to the fish population, zone $\mathrm{C}$ represents concern and prevention of flow reduction, and zone $\mathrm{D}$ shows Adverse Resource Impacts (ARI) to the fish population. The threshold between zone A and $\mathrm{B}$ represents a $10 \%$ reduction in the thriving fishes population. The threshold between zone $\mathrm{B}$ and $\mathrm{C}$ shows a $20 \%$ reduction in the thriving fishes population. The line between zone $\mathrm{C}$ and $\mathrm{D}$ is called the ARI line, which shows the threshold of flow reduction for causing ARI to characteristic fish species. This corresponds to $10 \%$ reduction in the characteristic fishes population (Zorn et al., 2008).

In order to define drought zones, first, the index flow for each stream in Saginaw Bay Watershed is determined. The SWAT model was run for 41 years, i.e. from 1972 to 2012, to simulate the daily streamflow data. Using this data, the lowest daily median flow values of the lowest summer month were calculated for each stream. Based on the Zorn et al. (2008) model criteria, four drought zones (A, B, C, and D) were defined: Zone A, representing the no drought condition, 
Zone $\mathrm{B}$, showing the moderate drought condition, Zone $\mathrm{C}$, indicating the severe drought conditions, and Zone D, referring to the extreme drought conditions. This information was used to create the reference table of drought zones (Table 1). Using the reference table, drought condition can be identified for each stream segment by multiplying the index flow (obtained from the SWAT model for the period of study 1972 to 2012) to correspondent value of Table 1.

\subsection{Drought Model Input Variables}

In this study, a total of 66 variables were initially considered for development of the drought model as independent variables. These variables were categorized as follows: precipitation (25 variables), streamflow (24 variables), land use ( 8 variables), soil ( 8 variables), and drainage area (1 variable).

The precipitation variables included the total precipitation for the month of interest, the total precipitation of each of the previous 12 months, and the average precipitation in past $n \in$ $\{1,2, \cdots, 12\}$ months was included, i.e. $\overline{p_{n}}=\sum_{0}^{n} \frac{p_{i}}{n+1}$, where $p_{i}$ is the precipitation of the i-th month before the month of interest. To further elaborate on the last group, the independent variable for $n=1$ correspond to the average precipitation of the month of interest and one month before that; when setting $n=2$ that corresponds to the average precipitation of the month of interest and that of the previous two months; and so on. The monthly average flow rates of the prior 1 to 24 months were also considered as independent variables. The land use was categorized as agricultural, forested, urban, and water areas. The actual area (4 variables) and percentage of these land uses ( 4 variables) for the area above each stream segment were calculated summing up to eight land use variables. Soil data was divided into four hydrologic soil groups of A, B, C, and D (NRCS, 2007). The soil groups were categorized based on their 
infiltration and water transmission rates. Group A soils, with gravel or sand texture, consist of gravel or sand $(>90 \%)$ and clay $(<10 \%)$. These soils have high infiltration and water transmission rates. Group B soils have a loamy sand or sandy loam texture and consist of 10$20 \%$ clay and $50-90 \%$ sand. These soils have moderate infiltration and water transmission rates. Group C soils, with loam or silt loam texture, have $20-40 \%$ clay and less than $50 \%$ sand. These soils have low infiltration and water transmission rates. Group D soils, with clayey texture, have more than $40 \%$ clay and less than $50 \%$ sand. The infiltration and water transmission rates of these soils are very slow (Cronshey et al., 1986; NRCS, 2007). Like the land use variables, the actual area and percentage values of each soil groups were calculated for each subbasin adding up to eight soil variables. The last variable was drainage area, which was calculated as the total area above the outlet of each stream segment.

\subsection{Variable Selection: ReliefF algorithm}

The ReliefF algorithm is a commonly used method for feature selection (Robnik-Sikonja and Kononenko, 2003). This method ranks the independent variables according to their relevance or importance in classifying or predicting the dependent variable (Kononenko, 1994; RobnikSikonja and Kononenko, 2003). The ReliefF algorithm is the improved version of the Relief algorithm, which was originally developed for binary classification (Kira and Rendell, 1992b; Robnik-Sikonja and Kononenko, 2003). ReliefF is capable of handling data with strong dependencies or outliers (Kononenko, 1994; Robnik-Sikonja and Kononenko, 2003; Mahlein et al., 2013).

For any given sample, ReliefF searches for the nearest neighborhoods of the same-class, also known as hits, and of the different-class, also known as misses. With $\mathrm{k}$ being the number of each neighborhood samples, there will be $\mathrm{k}$ nearest hits and $\mathrm{k}$ nearest misses for each sample. The 
nearest hits and misses are usually defined by the Euclidean distance (L2 norm) or Manhattan distance (L1 norm). The relevance of variables are determined by the sum of the Euclidean distance, or the Manhattan distance, between the nearest hits and nearest misses of all samples (Robnik-Sikonja and Kononenko, 2003; Mahlein et al., 2013), as follows:

$$
W_{i}=W_{i}-|| s_{i}-\left.N H_{i}\right|_{n}+|| s_{i}-\mathrm{NM}_{\mathrm{i}}||_{\mathrm{n}}
$$

Where, $n$ is equal to 1 for the Manhattan distance and is equal to 2 for the Euclidean distance, $s_{\mathrm{i}}$ is the i-th sample, $N H_{\mathrm{i}}$ is a set of $\mathrm{k}$ nearest-hit to the $s_{\mathrm{i}}$, and $N M_{\mathrm{i}}$ is a set of k nearest-miss to the $s_{\mathrm{i}}$, and $W_{\mathrm{i}}$ is the weight of the feature. This equation is set up in such a way that each feature is penalized, if it differs greatly from that of the nearest-hits, and rewarded otherwise, in case of nearest-misses.

ReliefF runtime scales linearly with the number of independent variables, i.e. if the number of independent variables are doubled, the algorithm would take twice as long. However, the computational requirement of the algorithm increases non-linearly with increasing sample size. This means that if the number of observations are doubled, the time needed to perform the required computation will increase more than twice. This is mostly due to the sorting and the distance calculation of each sample to all the other samples, which results to $n(n-1) / 2$ distinct distance values that are required to determine the nearest-hits and nearest-misses. In this study, there were more than 6.6 million observations (13831 streams $\times 40$ years $\times 12$ months), where each observation has 66 independent variables. Having these many observations made it impossible to use a single ReliefF run. Therefore, a subset of 10,000 samples was randomly selected from the original data set, and ranked. This procedure was repeated 2500 times; 
resulting in 2500 different rankings for each independent variable. A histogram of the ranking for each independent variable was constructed and averaged to determine the final score.

Selected variables were then used to accomplish two general goals: 1) Develop the most accurate drought model capable of determining current drought severity for all stream segments within the study area. This model is called the Current Drought Severity Model and was tested by using three sets of variables (the top 5, 10, and 15 ranked variables obtained from ReliefF) (Table S1). 2) Develop the most accurate drought forecast model capable of predicting future drought severity. This model is called the Future Drought Severity Model and was tested against three sets of variables that include all precipitation and streamflow variables from 6,12 , and 18 months prior to the month of interest.

\subsection{Partial Least Square Regression}

The partial least square regression (PLSR) is a statistical approach used for modeling linear relations between multivariate measurements (de Jong, 1993; Wold et al., 2001). However, the main advantage of PLSR over general linear regressions is its ability to deal with strongly collinear, noisy, incomplete, and large arrays of independent variables (Wold et al., 2001; Carrascal et al., 2009).

In order to train, test, and select the best PLSR model, 10-fold cross validation was used. In 10fold cross-validation, the dataset is randomly divided into 10 equally sized exclusive subsets or folds. Nine folds of the data are used for training (90\%) and the remaining (1-fold) is used for testing (10\%) (Hamaamin et al., 2013). This process was repeated 10 times with a new nonoverlapping testing fold until all folds were used for testing the PLSR model. 
For the development of both current and future drought severity models, PLSR was used to predict the relationship between the median flow of each stream segment for the month of interest (dependent variable) and the independent variables (Table S1). The initial test showed that the observed median flow is highly skewed; therefore, the dependent and independent variables were transformed using $\log _{10}$ transformation before the model development.

In order to evaluate the performance of these models, the accuracy, precision, and sensitivity of each model, in predicting drought zones, were determined. Accuracy refers to the overall correctness of the model (Eq. 2). Precision is an estimate of how correct the model outputs are for each class (Eq. 3). Sensitivity (Eq. 4) refers to the model ability to correctly pick instances of a certain class (Aruna et al., 2011). Accuracy, precision and sensitivity are calculated as follows:

$$
\begin{aligned}
& \text { accuracy }=\frac{T P+T N}{P+N} \\
& \text { precision }=\frac{T P}{T P+F P} \\
& \text { sensitivity }=\frac{T P}{P}=\frac{T P}{T P+F N}
\end{aligned}
$$

Where, $P$ stands for the number of positive cases and $N$ stands for the number of negative cases. The definition of positive and negative changes depending on what is being evaluated. For example, if the model is evaluating the presence or absence of the drought, then $P$ indicates the number of observations point that drought is present and $N$ represents those observations that show no sign of drought. While considering the definition of the positive and negative, $T P$ stands for True Positive, meaning observations that are positive and they are correctly classified as positive. $T N$ stands for True Negative, meaning observations that are negative and they are correctly classified as negative. FP, stands for False Positive, meaning the observations that are 
negative but mistakenly classified as Positive. Finally, FN stands for False Negative, meaning the observations that are positive but mistakenly classified as negative.

\subsection{Climate Models}

In this study, 16 different general circulation models (GCMs) from the Coupled Model Intercomparison Project Phase 5 (CMIP5) were used. CMIP5 aims to provide a multi-model dataset including long term and near term experiments that offer better understanding of climate change and climate variability (Taylor et al., 2012). The long-term experiments were used in this study, which range from mid-1900 to 2100 and beyond (Taylor et al., 2012). The names, modeling centers, atmospheric resolutions, and their components are listed in Table 2. For each GCM, data driven by three Representative Concentration Pathways (RCPs) scenarios (RCP4.5, RCP6.0, and RCP8.5 (Moss et al., 2010) was extracted for the future period of 2040-2060 and the historical period of 1980-2000. The latter is referred to as the control period data. Additionally, the weather station data for daily observation for the same time period as control data were obtained from the NCDC and used as the baseline in the analysis. The locations of these weather stations are presented in Figure S1.

The climate is projected to change significantly in the future and such changes are associated with large uncertainty, which cannot be neglected for impact assessments, especially when extreme situations are of the primary concern (IPCC, 2013). In impact assessment studies, one way to take uncertainty into consideration is by adopting an ensemble approach where the ensemble could refer to differences in the models, emission scenarios, initial conditions, etc. (Parker, 2013). In the current study, the ensemble was constructed based on different GCMs and emission scenarios. Although many other downscaling methods like quantile mapping, multiple regression, and artificial neural networks exist in the literatures (Maraun et al., 2010; Winkler et 
al., 2011a and 2011b; Hessami et al., 2008; Sailor et al., 2000; Hewitson and Cran et al. 1996; Schoof and Pryor et al., 2001), the delta method is chosen in the current study due to its ability to produce a large ensemble of projections (Winkler et al., 2011b). The delta method is also widely used in hydrological studies (Morrison et al., 2002; Merritt et al., 2006; Adam et al., 2009; Elsner et al., 2010; Dessu and Melesse, 2013; Adhikari and Nejadhashemi, 2016).

The assumptions of the delta methods are as following: a) relative change is better simulated by GCMs compared to absolute values (Fowler et al, 2007; Loukas et al., 2007), b) the number and temporal sequence of wet days remains unchanged (Fowler et al, 2007; Dessu et al., 2013; Htut et al., 2014), c) the GCMs biases for both mean and variability will be similar for the control and future periods, ignoring GCMs biases in the distribution of simulated variables (Boyer et al., 2010; Winkler et al., 2011b; Htut et al., 2014), and d) the spatial pattern and temporal variability of the present climate is maintained in the future (Diaz-Nieto and Wilby, 2005; Boyer et al., 2010). Meanwhile, the delta method has similar limitations including stationary that does not account for variability of natural systems (McCarl et al., 2008; Milly et al., 2008). This will affect the future projection of hydrological variables especially low flow events, which are significantly affected by precipitation variabilities (Lofgren and Gronewold, 2014).

The delta method was used to downscale the climate data to allow local scale analysis and for the impact model, which requires data inputs at daily time steps. The variables used in the delta method included the daily maximum temperature, daily minimum temperature, and daily total precipitation. In the delta method, the difference/ratio between the future and control period were calculated for the monthly averaged daily temperature/precipitation, and then applied to the observed daily time series. The temperature change factors are additive and can be negative 
values. On the other hand, the precipitation change factors are calculated as ratios with precipitation being zero bounded (Woznicki and Nejadhashemi, 2012).

\section{Results \& Discussions}

\subsection{SWAT Model Calibration and Validation}

The results of SWAT model calibration and validation, using statistical criteria, such as NSE, RSR, and PBIAS, are presented in Table 3. The reported NSE, RSR, and PBIAS are the overall values for both the calibration and validation for the period of 2001 to 2010 . The SWAT model met the statistical criteria for all nine USGS stations according to evaluation criteria, defined by Moriasi et al. (2007), the performance rating for all of the stations are in the range of very good, good, and satisfactory. Therefore, the model can be used to simulate streamflow data for the region satisfactorily.

\subsection{Variable Selection}

\subsubsection{Current Drought Severity Model}

The ReliefF algorithm was used for the development of the most accurate drought model capable of determining current drought severity for all streams. The ranking of all 66 variables is

presented in the histogram map (Figure 5). The y-axis represents the 66 independent variables, and the $\mathrm{x}$-axis represents their ranking. The color in Figure 5 shows how often a variable has obtained a certain rank during the 2500 different random sampling. The final number was normalized to scale between 0 and 1 (abundance). The dark blue indicates that the variable never obtained that rank. As the color spectrum moves from dark blue to dark red, it indicates that the variable obtained that rank more often than other independent variables. As an example, Figure S2 shows the histogram of the ranking of variable \#20 (average flow rate from 23 months prior 
to the month of interest). This variable mostly obtained rank 7 during 2500 iterations. Therefore, in Figure 5, on line 20, rank 7 is being shown the most red. The final ranking for each variable was determined based on the average of these 2500 different ranking.

In general, the average flow rate variables were ranked much higher than any other type of variables (Figure 5). This is mainly due to the high correlation between median flow and average flow rate. After the average flow rate variables, the precipitation variables were ranked the highest. This indicates that the stream system in general is less flashy during the dry season and more influenced by the groundwater system. Therefore, the median flow is not as dependent on precipitation as it was to the average flow rate. Finally, the physiographical variables were shown to be the least related to the changes in the median flow indicating that the changes to the median flow are insensitive to the total drainage area, land use, and soil type.

Out of the 66 original variables, the top 5, 10, and 15 ranked variables were used to develop three sets of drought models. The list of the top 15 ranked variables are presented in Table 4. All of the top ranked variables are related to flow rate. The only difference between the variables is the month from which the flow rate was calculated.

\subsubsection{Future Drought Severity Model}

The future drought severity model should be capable of predicting drought conditions for all streams within an area of interest. The results from the ReliefF analysis showed that the physiographical variables were the least related to the median flow. Therefore, they were not considered for the model development (Table S1). Overall, three sets of variables, all from 6, 12, and 18 months prior to the month of interest, were used in order to predict the future drought 
severity 6,12 , and 18 months in advanced, respectively. These variables included all average flow rate and precipitation variables for their respected period (Table S1).

\subsection{Drought Severity Model}

\subsubsection{PLSR model predictability for median flow}

The statistical analysis of the Current Drought Severity Model performances is presented in Table 5. Three models were developed using the top 5, 10, and 15 ranked variables. 10-fold cross validation was used to insure that the models were not over-trained or over-fitted by increasing the number of PLSR components. Mean Square Error (MSE) obtained from the 10-fold cross validation decreased asymptotically by increasing the number of PLSR components (Figure S3). This shows that the model is not over-fitted because the MSE values do not increase when incorporating more PLSR components.

The performance of each model was studied on all streams and on stream orders ( 1 to 7$)$. In the case of all streams, there is little to no change in $R^{2}$ values $(0.86)$ between the three models (Table 5). This indicates that including additional variables does not improve the models' performances. When comparing the models' performances based on different stream orders, stream order 6 and 7 ( $<2 \%$ of all streams) are exceptions in which $R^{2}$ values slightly improve as the number of independent variables increase (Table 5). However, improvement in model predictability is minimal ( $R^{2}$ for stream order 6 will be changed from 0.64 in model 1 to 0.66 for the model 3) while the number of independent variables tripled from 5 to 15 , respectively.

As presented in Figure 6, the first, second, and third PLSR models were able to explain 86.5\%, $87 \%$ and $87.1 \%$ of the variance of the output (median flow), respectively. Since the difference between these three models are not considerable; the first model, which requires the least number 
of independent variables, was selected as the best predictive Current Drought Severity Model for this study.

The statistical analyses for the Future Drought Severity Model performances are shown in Table 6. Similar to the Current Drought Severity Model, three models were evaluated using three sets of variables (flow rate and precipitation variables from 6,12, and 18 months prior to the month of interest). The same procedure (10-fold cross validation) was used for the fourth, fifth, and sixth models to make sure the models are not over-fitted by increasing the number of PLSR components. The MSE of the Future Drought Severity Models was similar to the Current Drought Severity Models, where the MSE values decreased asymptotically by increasing the number of PLSR components, Figure S4.

Among these models, the fourth and fifth models have higher $R^{2}$ values (0.85) and thus perform better than the sixth model $\left(R^{2}=0.76\right)$. Similarly, with respect to the stream order, both the fourth and fifth model performed better than the sixth model. The lower $R^{2}$ value for the sixth model is due to its PLSR model deficiency in explaining the output variance (Figure S5). The fourth and the fifth model can explain more about $84 \%$ of the variance; however, the sixth model can explain $75 \%$ of the variance at most, Figure S5. This could be due to the fact that the variables used to predict drought 18 months in advance are not sensitive enough to detect future drought conditions.

The histogram of measured and predicted median flow obtained from the Current and Future Drought Severity Models are presented in Figures 7 and S6, respectively. The horizontal axis represents the $\log _{10}$ of the median flow values and the vertical axis represents the number of counts. Overall, the histogram of the predicted median flows is very similar to the histogram of 
the measured flows for all models. However, the peak in the predicted histogram is higher than the peak in the measured histogram. This difference was most pronounced for the sixth model (Figure S6). Therefore, it is expected that the error level is higher at the higher and lower median flow rates due to the shift from the two tails of the distribution for the sixth model to the peak of the median flow rates. This also explains the lower $R^{2}$ values for the sixth model $\left(R^{2}=0.76\right)$.

\subsubsection{Accuracy, precision, and sensitivity of drought models in predicting drought zones}

For each model, drought zones were identified by comparing the predicted median flow values against the reference table for the drought zones (Table 1). The results from the six drought severity models are summarized in six confusion matrices (Tables 7-8 and S2-S5). The diagonal of the matrix shows the number of zones that have been correctly classified by the model. The overall accuracy of the model is determined by dividing the sum of the diagonal values by the sum of the all values of the matrix. As seen in Tables 7-8 and S2-S5, the first model through fifth model have an accuracy higher than 70\%. However, the sixth model has accuracy of only $59 \%$. This reflects the conclusions drawn in the previous section that the sixth model has a lower predictability than the other developed models.

In general, all models have lower sensitivities and precisions for zone $\mathrm{B}$ and $\mathrm{C}$ compared to zone A and D. Especially for zone C, all cases had a sensitivity and precision percentage below $8 \%$. This low predication is due to the small range that zone $\mathrm{B}$ and $\mathrm{C}$ cover. As mentioned earlier, there are eleven different classes of streams based on their sizes and temperature (Zorn et al., 2008), and each of these classes have specific index flow zoning ranges. For zone B and C and all stream classes, the zoning ranges cover only $10 \%$ or less of the index flow, while the remaining index flow reduction is covered by zone A and D. Therefore, accurately predicting 
these small ranges can be difficult, which ultimately reduce the sensitivity and precision of the models for zones B and C.

When comparing the performance of the Current Drought Severity Models, the first model performed the best. The first model had a higher accuracy, precision, and sensitivity compared to the other models. Among the Current Drought Severity Models (Tables 7, S2, and S3), the first model has higher precision in classifying zone A $(83 \%)$, and lower precision in classifying zone D (67\%). In addition, it has a higher sensitivity in classifying zone D (66\%), and slightly lower sensitivity in classifying zone A (84\%). Therefore, it was concluded that the first model is the best among the Current Drought Severity Models.

Among the Future Drought Severity Models, the fourth model performed slightly better than the fifth model. The fourth model has a slightly better accuracy (71\%), a better precision in classifying zone D (62\%), and a better sensitivity in classifying zone A (84\%) compared to the fifth model. The sixth model, as expected, has a low accuracy (59\%), precision, and sensitivity among all models. Therefore, it was concluded that the fourth model is the best among the Future Drought Severity Models.

\subsection{Drought model performance under future climate scenarios}

In order to evaluate the capabilities of the drought models in predicting future drought caused by climate change, the best-selected drought model (the first model) was used. The predicted values resulting from the first model were compared with the calibrated SWAT model. In this section, zone $\mathrm{A}$ is referred to as the no-drought condition, and zones $\mathrm{B}, \mathrm{C}$ and $\mathrm{D}$ are combined and denoted as drought conditions. 
The results for the first drought model performance against each climate change scenario are presented in Tables S6 through S8. The overall performance of the first model for predicting future median flow and drought conditions are presented in Table 9. Based on $R^{2}$ values, HadGEM2-ES performed better than the other models under RCP 8.5 and RCP 4.5. Under RCP 6.0, MIROC5 performed better than rest of the models. However, as shown in Table 9, the $R^{2}$ values among the models ranged from 0.86 to 0.89 (based on transformed values) and 0.48 to 0.66 (based on actual values). In addition, it has a high accuracy in predicting nodrought/drought condition (on average above $80 \%$ ). The low standard deviation (0.0187) shows the consistency of the model performance under different climatic conditions.

\subsection{The impact of climate change on future drought}

The first model, which is the best model, was run for the 47 future climate scenarios for the period of 2040 to 2060 to understand the impacts of climate change on drought in the context of stream health. In addition, the status of drought conditions for the current period, 1990 to 2010 , was evaluated to provide a reference condition in which future drought will be evaluated against. The future and current drought conditions were compared with each other using a cumulative distribution function (CDF) for all reaches within the Saginaw Bay Watershed, Figure 8. The probability of increasing drought conditions is categorized into four equal intervals. Reaches drawn as green show lower climb in drought probability while reaches drawn in red show higher probability of drought occurrences under future climate conditions. In general, the majority of the reaches $(94 \%)$ will experience higher drought probability under future climate scenarios compared to current conditions. Specifically, the mid-section of the watershed will experience the highest probabilities (66.68\% to $100 \%)$ for future drought. In order to understand the possible causation for the increased drought in this region, the percent change maps for the two main 
drivers of drought (precipitation and temperature) were created (Figure 9). The percent change map of average temperature, Figure 9a, shows warmer temperatures are expected for all streams in the region due to an increase in average air temperature $\left(2.3^{\circ} \mathrm{C}\right)$. However, the region with the lowest increase in of precipitation $(3.22 \%$ to $4.31 \%)$ was almost identical to the region of the worst future drought conditions (66.68\% to $100 \%)$. This indicates that precipitation has a major impact on future drought conditions. It can also be concluded that the stream system in the area of interest (high drought probability region) is predominately fed by surface runoff while the rest of the watershed is predominately groundwater fed.

\section{Conclusion}

Drought is the world's costliest natural disaster, affecting both human and natural systems. Several drought indices have been developed to study the impacts of drought on the human dimension. However, this study is unique since the objective was to define a new drought index and predictive model in the context of stream health.

The concept of the index flow was adapted from the Regional-scale Habitat Suitability Model to define the dought zones. Initially, 66 variables were considered for development of the drought model. Variables were selected to develop two set of models: 1) the most accurate drought model capable of determining current drought severity and 2) the most accurate drought forecast model capable of predating future drought severity. For the Current Drought Severity Models, the ReliefF algorithm was used to identify the top 15 ranked variables and for the Future Drought Severity Models, three models using some variables from 6, 12, and 18 months prior to the month of interest, respectively, were used. In general average flow rate and precipitation were among the highest ranked variables that were used for development of drought models. It is 
expected that these variables are applicable to other watersheds simplifying the parameter selections for future studies.

Six drought models were developed using PLSR. The drought models were evaluated for median flow, classifying drought zones, and no-drought/drought conditions. Among the Current Drought Severity Models, the first model with five variables, having the highest $R^{2}(0.86)$ and accuracy (0.74), was selected as the best; while the fourth model with 34 variables, having the highest $R^{2}$ value $(0.85)$ and accuracy $(0.71)$, was selected as the best model among the Future Drought Severity Models. Overall, the first model was selected as the best model to predict drought severity.

The first model predictability was also tested using 47 future climate models, in which $R^{2}$ values varied from 0.87 to 0.89 . In addition, the average accuracy of the no-drought/drought ratio is 0.81. The future and current drought conditions were compared with each other using CDF curves and maps for all reaches within the Saginaw Bay Watershed. Approximately $7.2 \%$ of streams are expected to experience high increase $(66.68 \%$ to $100 \%)$ in drought frequency under future climate scenarios. This region is highly correlated to the region that will experience the lowest increase in precipitation (3.22\% to $4.31 \%)$, while the average temperature rises for the entire watershed is about $2.3{ }^{\circ} \mathrm{C}$.

This study introduced a new concept of evaluating the impact of drought on the stream health. This is important since the introduced concept and modeling techniques can provide a road map for better allocation of resources to mitigate the impacts of the climate change on aquatic systems. The technique presented here is robust and transferable to other watersheds around the world with regional standards for environmental flow. Due to limitations of the delta method, 
future studies should explore additional resources of climate data and methods for downscaling and bias correction in the development of the climate change ensemble.

\section{Acknowledgments}

This work is supported by the USDA National Institute of Food and Agriculture, Hatch project MICL02359. Also, we would like to thank the climate modeling groups (listed in Table 3 of this paper) for producing and making their model outputs available. Additional thanks go to the World Climate Research Programme's Working Group on Coupled Modelling, which maintains the CMIP database and promotes the sharing of climate model outputs. Furthermore, we would like to thank the U.S. Department of Energy's Program for Climate Model Diagnosis and Intercomparison, which provides coordinating support and development of software infrastructure in partnership with the Global Organization for Earth System Science Portals. The

climate projections were developed with funding from the National Science Foundation under Grant BCS-0909378. Any opinions, findings, and conclusions or recommendations expressed in this material are those of the authors and do not necessarily reflect the views of the National Science Foundation.

\section{Reference}

Adam, J. C., Halmet, A. F., Lettenmaier, D. P., 2009. Implications of global climate change for snowmelt hydrology in the twenty-first century. Hydrol. Process. 23(7), 962-972.

Adhikari, U., Nejadhashemi, A. P., 2016. Impacts of climate change on water resources in Malawi. J. Hydrol. Eng., ASCE, in press.

Alley, W. M., 1984. The Palmer drought severity index: limitations and assumptions. J. Clim. Appl. Meteorol. 23(7), 1100-1109. 
American Meteorological Society, 1997. Meteorological drought—Policy statement. Bull. Amer. Meteor. Soc. 78, 847-849.

Aruna, S., Rajagopalan, S.P., Nandakishore, L.V., 2011. Knowledge based analysis of various statistical tools in detecting breast cancer. CCSEA, CS \& IT 02. 37-45.

Barbour, M.T., Gerritsen J., Snyder B.D., Stribling J.B., 1999. Rapid Bioassessment Protocols for Use in Streams and Wadeable Rivers: Periphyton, Benthic Macroinvertebrates and Fish, Second Edition. EPA 841-B-99-002. U.S. Environmental Protection Agency. Office of Water; Washington, D.C.

Boyer, C., Chaumont, D., Chartier, I., Roy, A. G., 2010. Impact of climate change on the hydrology of St. Lawrence tributaries. J. Hydrol. 384(1-2), 65-83.

Bunn, S. E., Arthington, A. H., 2002. Basic principles and ecological consequences of altered flow regims for aquatic biodiversity. Environ. Manage. 30(4), 492-507.

Cancelliere, A., Di Mauro, G., Bonaccorso, B., Rossi, G., 2007. Drought forecasting using the Standardized Precipitation Index. Water. Resour. Manag. 21(5), 801-819.

Carlisle, D. M., Meador, M. R., Short, T. M., Tate, C. M., Gurtz, M. E., Bryant, W. L., Falcone, J. A., Woodside, M. D., 2013, The quality of our Nation's waters-Ecological health in the Nation's streams, 1993-2005. U.S. Geological Survey Circular 1391, 120. (Online) http://pubs.usgs.gov/circ/1391/.

Carrascal L. M., Galva'n I., Gordo O., 2009. Partial least squares regression as an alternative to current regression methods used in ecology. Oikos. 118, 681-690. 
Cronshey, R., McCuen, R., Miller, N., Rawls, W., Robbins, S., Woodward, D., 1986. Urban hydrology for small watersheds. U.S. Dept. of Agriculture, Soil Conservation Service, Engineering Division.

Dai, A. G., Trenberth, K. E., Qian, T. T., 2004. A global data set of Palmer drought severity index for 1870-2002: relationship with soil moisture and effects of surface warming. J. Hydrometeorol. 5(6), 1117-1130.

Davies, S. P., Jackson, S. K., 2006. The biological condition gradient: a descriptive model for interpreting change in aquatic ecosystems. Ecol. Appl. 16(4), 1251-1266.

de Jong, S., 1993. SIMPLS: an alternative approach squares regression to partial least. Chemometr. Intell. Lab. Syst. 18, 251-263.

Dessu, S. B., Melesse, A. M., 2013. Impact and uncertainties of climate change on the hydrology of the Mara River basin, Kenya/Tanzania. Hydrol. Process. 27(20), 2973-2986.

Diaz-Nieto, J., Wilby R. L. 2005. A comparison of statistical downscaling and climate change factor methods: Impacts on low flows in the River Thames, United Kingdom. Clim. Change. 69, 245-268.

Einheuser, M. D., Nejadhashemi, A. P., Wang, L., Sowa, S. P., Woznicki, S. A. 2013. Linking biological integrity and watershed models to assess the impacts of historical land use and climate changes on stream health. Environ. Manage. 51(6), 1147-1163.

Elsner, M. M., Cuo, L., Voisin, N., Deems, J. S., Hamlet, A. F., Vano, J. A., Mickelson, K. E. B., Lee, S. Y., Lettenmaier, D. P., 2010. Implications of 21 st century climate change for the hydrology of Washington State. Climatic Change. 102, 225-260. 
Feyen, L., Dankers, R., 2009. Impact of global warming on streamflow drought in Europe. J. Geophys. Res. 114(D17).

Flinders, C. A., Horwitz, R. J., Belton, T., 2008. Relationship of fish and macroinvertebrate communities in the mid-Atlantic uplands: Implications for integrated assessments. Ecol. Indic. 8(5), 588-598.

Fowler, H. J., Blenkinsop, S., Tebaldi, C., 2007. Review: Linking climate change modeling to impacts studies: recent advances in downscaling techniques for hydrological modelling. Int. J. Climatol. 27, 1547-1578.

Gassman, P. W., Reyes, M. R., Green, C. H., Arnold, J. G., 2007. The soil and water assessment tool: historical development, applications, and future research directions. T. ASABE. $50(4), 1211-1250$

Golden, H. E., Sander, H. A., Lane, C. R., Zhao, C., Price, K., D'Amico, E., \& Christensen, J. R., 2016. Relative effects of geographically isolated wetlands on streamflow: a watershedscale analysis. Ecohydrology. 9(1), 21-38.

Gustard, A., Bullock, A., Dixon, J. M., 1992. Low flow estimation in the United Kingdom. Institute of Hydrology, Report No. 108. (Online) http://nora.nerc.ac.uk/6050/1/IH_108.pdf

Hamaamin, Y. A., Nejadhashemi, A. P., Einheuser, M. D., 2013. Application of fuzzy logic techniques in estimating the regional index flow for Michigan. T. ASABE. 56(1), 103115. 
Hamilton, D. A., Seelbach, P. W., 2011. Michigan's water withdrawal assessment process and internet screening tool. Michigan Department of Natural Resources, fisheries Special Report 55.

Hart, D. D., Finelli, C. M., 1999. Physical-biological coupling in streams: The pervasive effects of flow on benthic organisms. Annu. Rev. Ecol. Syst. 30:363-95.

Hayes, M. J., 2006. Drought indices. What is Drought? Lincoln, Nebraska: National Drought Mitigation Center.

Heim, R. R., 2000: Drought indices: A review. In: Wilhite, D.A. (Ed.), Drought: A Global Assessment, Routledge, New York. 159-167.

Heim, R., R., 2002. A review of twentieth-century drought indices used in the United States. Bull. Am. Meteorol. Soc. 83(8), 1149-1165.

Hessami, M., Gachon, P., Ouarda, T. B. M. J., St-Hilaire, A., 2008. Automated regression-based statistical downscaling tool. Environ. Modell. Softw. 23(6), 813-834.

Hewitson, B. C., Crane, R.G., 1996. Climate downscaling: techniques and application. Clim. Res.7, 85-95.

Htut, A. Y., Shrestha, S., Nitivattananon, V., Kawasaki, A., 2014. Forecasting climate change scenarios in the Bago River Basin, Myanmar. J. Earth Sci. Clim. Change. 5(9).

Institute of Hydrology 1980. Low Flow Studies report. Wallingford, UK.

IPCC, 2013: Climate Change 2013: The Physical Science Basis. Contribution of Working Group I to the Fifth Assessment Report of the Intergovernmental Panel on Climate Change 
[Stocker, T.F., D. Qin, G.-K. Plattner, M. Tignor, S.K. Allen, J. Boschung, A. Nauels, Y. Xia, V. Bex and P.M. Midgley (eds.)]. Cambridge University Press, Cambridge, United Kingdom and New York, NY, USA, 1535.

Johnson, W. K., Kohne, R. W., 1993. Susceptibility of reservoirs to drought using Palmer index. J. Water Resour. Plann. Manage. 119 (3), 367-387.

Karr, J. R., Dudley, D. R., 1981. Ecological perspectives on water quality goals. Environ. Manag. 5(1), 55-68.

Keyantash, J., Dracup, J. A., 2002. The quantification of drought: an evaluation of drought indices. The drought monitor. Bull. Am. Meteorol. Soc. 83 (8), 1167-1180.

Kim, T. W., Valdes, J. B., 2003. Nonlinear model for drought forecasting based on a conjunction of wavelet transforms and neural networks. J. Hydrol. Eng. 8 (6), 319-328.

Kira, K., Rendell, L. A., 1992b. A practical approach to feature selection. Proceedings 9th International Conference on Machine Learning, Aberdeen, Scotland, Morgan Kaufmann, San Mateo, CA, 249-256.

Kogan, F. N., 1995. Droughts of the late 1980s in the United States as derived from NOAA polar-orbiting satellite data. Bull. Amer. Meteor. Soc., 76(5), 655-668.

Kogan, F. N., 2005. NOAA/AVHRR satellite data-based indices for monitoring agricultural droughts In Boken, V. K., Cracknell, A., Heathcote, P., eds., Monitoring and Predicting Agricultural Drought: A Global Study. New York: Oxford University Press, 79-88.

Kononenko, I., 1994. Estimating attributes: Analysis and extensions of relief. Proceedings 7th European Conference on Machine Learning, 171-182. 
Koster, B. S., Bunn, S. E., Mackay, S. J., Poff, N. L., Naiman, R. J., Lake, P. S., 2010. The use of Bayesian networks to guide investments in flow and catchment restoration for impaired river ecosystems. Freshwater Biol. 55(1), 243-260.

Lake, P. S., 2003. Ecological effects of perturbation by drought in flowing waters. Freshwater Biol. 48(7), 1161-1172.

Lofgren, B., Gronewold, A., 2014. Water resources, in: Climate Change in the Midwest: A Synthesis Report for the National Climate Assessment, J.A. Winkler, J.A. Andresen, J.L. Hatfield, D. Bidwell, and D. Brown, eds. Island Press, 224-237.

Loukas, A., Vasiliades, L., Tzabiras, J., 2007. Evaluation of climate change on drought impulses in Thessaly, Greece. Eur. Water. 17/18(1), 17-28.

Mahlein, A. -K., Rumpf, T., Welke, P., Dehne, H. -W., Plümer. L., Steiner, U., Oerke, E. -C., 2013. Development of spectral indices for detecting and identifying plant diseases. Remote Sens. Environ. 128, 21-30.

Maraun, D., Wetterhall, F., Ireson, A. M., Chandler, R. E., Kendon, E. J., Widmann, M., Brienen, S., Rust, H. W., Sauter, T., Themessl, M., Venema, V. K. C., Chun, K. P., Goodess, C. M., Jones, R. G., Onof, C., Vrac, M., Thiele-Eich, I., 2010. Precipitation downscaling under climate change: recent developments to bridge the gap between dynamical models and the end user. Rev. Geophys. 48, 1-34.

McCarl, B.A., Villavicencio, X., Wu, X., 2008. Climate change and future analysis: is stationarity dying? Am. J. Agr. Econ., 90, 1241-1247. 
McKee, T. B., Doesken, N. J., Kleist, J., 1993. The Relationship of Drought Frequency and Duration to Time Scales. Preprints, Eighth Conference on Applied Climatology, Anaheim, CA, Amer. Meteor. Soc., 179-184.

McKee, T. B., Doesken, N.J., Kleist, J., 1995. Drought Monitoring with Multiple Time Scales. Proceeding of the Ninth Conference on Applied Climatology, Dallas, Texas. Amer. Meteor. Soc.

Mcmahon, T. A., Finlayson, B. L., 2003. Droughts and anti-droughts: the low flow hydrology of Australian rivers. Freshwater Biol. 48(7), 1147-1160.

Merritt, W. S., Alila, Y., Barton, M., Taylor, B., Cohen, S., Neilsen, D., 2006. Hydrologic response to scenarios of climate change in sub watersheds of the Okanagan basin, British Columbia. J. Hydrol. 326(1-4), 79-108.

Meyer, J. L., 1997. Stream health: incorporating the human dimension to advance stream ecology. J. N. Am. Benthol. Soc. 16(2), 439-447.

Milly, P.C.D., Betancourt, J., Falkenmark, M., Hirsch, R.M., Kundzewicz, Z.W., Lettenmaier, D.P., Stouffer, R.J., 2008. Stationarity is dead: whither water management? Science 319, $573-574$.

Mishra, A. K., Desai, V. R., 2005a. Drought forecasting using stochastic models. Stoch. Env. Res. Risk A. 19(5), 326-339.

Mishra, A. K., Desai, V. R., 2005b. Spatial and temporal drought analysis in the Kansabati River Basin, India. Int. J. River Basin Manag. 3(1), 31-41. 
Mishra, A. K., Desai, V. R., Singh, V. P., 2007. Drought forecasting using a hybrid stochastic and neural network model. J. Hydrol. Eng. 12(6), 626-638.

Mishra, A. K., Singh, V. P., 2009. Analysis of drought severity-area-frequency curves using a general circulation model and scenario uncertainty. J. Geophys. Res. 114(D6).

Mishra, A. K., Singh, V. P., 2010. A review of drought concepts. J. Hydrol. 391, 202-216.

Moriasi, D. N., Arnold, J. G., Van Liew, M. W., Blingner, R. L., Harmel, R. D., Veith, T.L., 2007. Model Evaluation Guidelines for Systematic Quantification of Accuracy in Watershed Simulations. T. ASABE. 50(3), 885-900.

Morrison, J., Quick, M. C., Foreman, M. G. G., 2002. Climate change in the Fraser river watershed: flow and temperature projections. J. Hydrol. 263(1-4), 230-244.

Moss, R. H., Edmonds, J. A., Hibbard, K. A., Manning, M. R., Rose, S. K., van Vuuren, D. P., Carter, T. R., Emori, S., Kainuma, M., Kram, T., Meehl, G. A., Mitchell, J. F. B., Nakicenovic, N., Riahi, K., Smith, S.J., Stouffer, R.J., Thomson, A.M., Weyant, J.P., Wilbanks, T.J., 2010. The next generation of scenarios for climate change research and assessment. Nature. 463, 747-756.

NASS, 2012. CropScape-Cropland Data Layer. United States Department of Agriculture: National Agricultural Statistics Service. (Online) http://nassgeodata.gmu.edu/CropScape/.

NED, 2014. National Elevation Dataset. (Online) http://ned.usgs.gov/index.html.

Neitsch, S. L., Arnold, J. G., Kiniry, J. R., Williams, J. R., 2011. Soil and water assessment tool theoretical documentation, version 2009. Temple, Tex.: USDA-ARS Grassland, Soil and 
Water Research Laboratory. (Online) http://swat.tamu.edu/media/99192/swat2009theory.pdf.

Nerbonne, B. A., Vondracek, B., 2001. Effects of local land use on physical habitat, benthic macroinvertebrates, and fish in the Whitewater River, Minnesota, USA. Environ Manage. 28(1), 87-99.

NRCS, 2007. Chapter 7: Hydrologic Soil Groups. National Engineering Handbook: Section 4: Part 630, Hydrologic Engineering. Washington, D.C.: U.S. Dept. of Agriculture, Soil Conservation Service.

NRCS, 2014a. Web Soil Survey. (Online) http://websoilsurvey.sc.egov.usda.gov/App/WebSoilSurvey.aspx.

Özger, M., Mishra, A. K., Singh, V. P., 2009. Low frequency variability in drought events associated with climate indices. J. Hydrol. 364, 152-162.

Palmer, W. C., 1968. Keeping track of crop moisture conditions, nationwide: The new crop moisture index. Weatherwise. 21 (4), 156-161.

Palmer, W.C., 1965. Meteorological drought. Research Paper 45, U.S. Dept. of Commerce,58.

Panu, U. S., Sharma, T. C., 2002. Challenges in drought research: some perspectives and future directions. Hydrol. Sci. J. 47, 19-30.

Parker, W. S., 2013. Ensemble modeling, uncertainty and robust predictions. WIREs Clim. Change. 4(3), 213-223. 
Petkova, E. P., Horton R. M., Bader, D. A., Kinney, P. L., 2013. Projected heat-Related Mortality in the U.S. Urban Northeast. Int. J. Environ. Res. Public Health. 10(12), 67346747.

Poff, N. L., Richter, B. D., Arthington, A. H., Bunn, S. E., Naiman, R. J., Kendy, E., Acreman, M., Apse, C., Bledsoe, B. P., Freeman, M. C., Henriksen, J., Jacobson, R. B., Kennen, J. G., Merritt, D. M., O'keeffe, J. H., Olden, J. D., Rogers, K., Tharme, R. E., Warner, A., 2010. The ecological limits of hydrologic alteration (ELOHA): a new framework for developing regional environmental flow standards. Freshwater Biol. 55(1), 147-170.

Qiao, F., Song, Z., Bao, Y., Song Y., Shu, Q., Huang, C., Zhao, W., 2013. Development and evaluation of an Earth System Model with surface gravity waves. J. Geophys. Res. 118(9), 4514-4524.

Quiring S. M., Ganesh, S., 2010. Evaluating the utility of the vegetation condition index (VCI) for monitoring meteorological drought in Texas. Agr. Forest Meteorol. 150(3), 330-339.

Rao, A. R., Padmanabhan, G., 1984. Analysis and modeling of Palmer's drought index series. J. Hydrol. 68(1-4), 211-229.

Robnik-Šikonja, M., \& Kononenko, I., 2003. Theoretical and empirical analysis of relieff and rrelieff. Mach. Learn. 53(1), 23-69.

Rouse, J. W., Haas, R. H., Deering, D. W., Schell, J. A., Harlan, J. C., 1974. Monitoring the vernal advancement and retrogradation (green wave effect) of natural vegetation. Final Report, RSC 1978-4, Texas A \& M University, College Station, Texas. 
Sailor, D. J., Hu, T., Li, X., Rosen, J. N., 2000. A neural network approach to local downscaling of GCM output for assessing wind power implications of climate change. Renew. Energy. 19(3), 359-378.

Schoof, J.T., Pryor, S.C., 2001. Downscaling temperature and precipitation: a comparison of regression-based methods and artificial neural networks. Int J Climatol. 21(7), 773-790.

Shafer, B. A., Dezman, L. E., 1982. Development of a Surface Water Supply Index (SWSI) to Assess the Severity of Drought Conditions in Snowpack Runoff Areas. In: Proc Western Snow Conference, Colorado State University, Fort Collins, Colorado. 164-175.

Sheffield, J., Wood, E. F., 2011. Droughts: Past Problems and Future Scenarios. London: Earthscan.

Singh, R. P., Roy, S., Kogan, F., 2003. Vegetation and temperature condition indices from NOAA AVHRR data for drought monitoring over India. Int. J. Remote Sens. 24(22), 4393-4402.

Smakhtin, V. U., 2001. Low flow hydrology: a review. J. Hydrol. 240(3-4), 147-186.

Tallaksen, L. M., Van Lanen, H. A.J., 2004. Hydrological drought processes and estimation methods for streamflow and groundwater. Amsterdam: Elsevier.

Taylor, K. E., Stouffer, R. J., Meehl, G. A., 2012: An overview of CMIP5 and the experiment design. Bull. Am. Meteorol. Soc. 93(4), 485-498.

USEPA, 2013. Great Lakes areas of concerns. Saginaw River and bay area of concern. (Online) http://www.epa.gov/glnpo/aoc/saginaw-river/index.html 
Wardlow, B. D., Anderson, M. C., Verdin, J. P., 2012. Remote Sensing of Drought: Innovative Monitoring Approaches. Boca Raton, FL: CRC Press.

Watanabe, M., Suzuki, T., O’ishi, R., Komuro, Y., Watanabe, S., Emori, S., Takemura, T., Chikira, M., Ogura, T., Sekiguchi, M., Takata, K., Yamazaki, D., Yokohata, T., Nozawa, T., Hasumi, H., Tatebe, H., Kimoto, M., 2010. Improved climate simulation by MIROC5: mean states, variability, and climate sensitivity. J. Clim. 23(23), 6312-6335.

Wilhite, D. A., Glantz, M. H., 1985. Understanding the drought phenomenon: the role of definitions. Water Int. 10(3), 111-120.

Wilhite, D. A., 2000b. Drought as a natural hazard: concepts and definitions. In: Wilhite, D.A. (Ed.), Drought: A Global Assessment, Routledge, New York. 1, 1-18.

Wilhite, D. A., Sivakumar, M. V. K., Pulwarty, 2014. Managing drought risk in a changing climate: The role of national drought policy. Weather Clim. Extremes. 3, 4-13.

Winkler, J. A., Guentchev, G., S., Perdinan, Tan P., -N., Zhong, S., Liszewska, M., Abraham, Z., Niedz'wiedz', T., Ustrnul, Z., 2011a, Climate scenario development and applications for local/regional climate change impact assessments: An overview for the non-climate scientist. Part I: Scenario development using downscaling methods. Geogr. Compass. 5(6) 275-300.

Winkler, J. A., Guentchev, G. S., Liszewska, M., Perdinan, Tan, P. -N., 2011b. Climate scenario development and applications for local/regional climate change impact assessments: An overview for the non-climate scientist. Part II: Considerations when using climate change scenarios. Geogr. Compass. 5(6), 301-328. 
Wold, S., Sjöström, M., Eriksson, L., 2001. PLS-regression: a basic tool of chemometrics. Chemometr. Intell. Lab. Syst. 58(2), 109-130.

Woznicki, S. A., Nejadhashemi, A. P., 2012. Sensitivity analysis of best management practices under climate change scenarios. J. AM. Water Resour. As. 48(1), 90-112.

Woznicki, S. A., Nejadhashemi, A. P., 2014. Assessing uncertainty in best management practice effectiveness under future climate scenarios. Hydrol. Process. 28(4), 2550-2566.

Zaidman, M. D., Rees, H. G., Young, A. R., 2001. Spatio-temporal development of streamflow droughts in north-west Europe. Hydrol. Earth Syst. Sc. 5(4), 733-751.

Zargar, A., Sadiq, R., Naser, B., Khan, F. I., 2011. A review of drought indices. Environ. Rev. 9, $333-349$.

Zorn, T. G., Seelbach, P. W., Rutherford, E. S., Wills, T. C., Cheng, S. -T., Wiley, M. J., 2008. A regional-scale habitat suitability model to assess the effects of flow reduction on fish assemblages in Michigan streams. Michigan Department of Natural Resources, Fisheries Research Report 2089, Ann Arbor. 


\section{Figure Captions:}

Figure 1: Saginaw Bay Watershed

Figure 2: Drought zones variable selection and modeling process.

Figure 3. Land cover map of the study area

Figure 4. Fish response curve to flow reduction (adapted from Zorn et al., 2008)

Figure 5. ReliefF ranking histogram map

Figure 6. The variance explained percentage for each PLSR for the Current Drought Severity Model: a) First model, b) Second model, c) Third model.

Figure 7. The comparison of measured vs. predicted median flow histogram for the Current Drought Severity Model, a) First model, b) Second model, c) Third model.

Figure 8. Probability of increasing drought conditions under projected climate change (20402060) compare to current condition (1980-2000).

Figure 9. Percent change in (a) temperature and (b) precipitation from current (1980-2000) to future climate change (2040-2060). 
Table 1. Reference table of drought zones based on different percentage of index flows (adapted from Hamilton and Seelbach, 2011)

\begin{tabular}{lcccc}
\hline Ecological Stream Types & Zone A & Zone B & Zone C & Zone D \\
\hline Cold Streams & $>86 \%$ & None & $>80 \%-86 \%$ & $\geq 80 \%$ \\
Cold Small Rivers & $>89.5 \%$ & None & $>79 \%-$ & $\geq 79 \%$ \\
& & & $89.5 \%$ & None \\
Cold Transitional Streams & None & $>96 \%$ & None & $\geq 96 \%$ \\
Cold Transitional Small & None & $>98 \%$ & \\
Rivers & & & None & $\geq 97 \%$ \\
Cold Transitional Large & None & $>97 \%$ & \\
Rivers & & $>85 \%-94 \%$ & $>75 \%-85 \%$ & $\geq 75 \%$ \\
Cool Streams & $>94 \%$ & $>81 \%-85 \%$ & $>75 \%-81 \%$ & $\geq 75 \%$ \\
Cool Small Rivers & $>85 \%$ & $>81 \%-86 \%$ & $>75 \%-81 \%$ & $\geq 75 \%$ \\
Cool Large Rivers & $>86 \%$ & $>82 \%-90 \%$ & $>76 \%-82 \%$ & $\geq 76 \%$ \\
Warm Streams & $>90 \%$ & $>87 \%-92 \%$ & $>83 \%-87 \%$ & $\geq 83 \%$ \\
Warm Small Rivers & & & $>78 \%-84 \%$ & $\geq 78 \%$ \\
Warm Large Rivers & & & & \\
\hline
\end{tabular}


Table 2. CMIP5 models developer, name, resolution, and components (Adapted from Petkova et al, 2013, IPCC, 2013)

\begin{tabular}{ccc}
\hline Modeling Center/ID & Model & $\begin{array}{c}\text { Atmospheric Resolution } \\
\text { (latitude } \times \text { longitude) }\end{array}$
\end{tabular}

The First Institute of

Oceanography/FIO

Institut Pierre-Simon

Laplace/IPSL

Atmosphere and Ocean Research Institute (The University of Tokyo), National Institute for Environmental Studies, and Japan Agency for Marine-Earth Science and Technology /MIROC

Japan Agency for Marine-Earth Science and Technology,

Atmosphere and Ocean Research Institute (The University of Tokyo), and National Institute for Environmental Studies/MIROC

Met Office Hadley Centre /MOHC

Meteorological Research Institute /MRI

NASA Goddard Institute for

\begin{tabular}{|c|c|c|}
\hline FIO-ESM & $2.8^{\circ} \times 2.8^{\circ}$ & $\mathrm{Atm}^{1}, \mathrm{Aero}^{2}, \mathrm{LS}^{4}, \mathrm{O}^{5}, \mathrm{OB}^{6}, \mathrm{SI}^{7}$ \\
\hline IPSL-CM5A-LR & $3.75^{\circ} \times 1.9^{\circ}$ & $\mathrm{Atm}^{1}, \mathrm{Aero}^{2}, \mathrm{LS}^{4}, \mathrm{O}^{5}, \mathrm{OB}^{6}, \mathrm{SI}^{7}$ \\
\hline IPSL-CM5A-MR & $2.5^{\circ} \times 1.25^{\circ}$ & $\operatorname{Atm}^{1}$, Aero $^{2}, \mathrm{LS}^{4}, \mathrm{O}^{5}, \mathrm{OB}^{6}, \mathrm{SI}^{7}$ \\
\hline MIROC5 & $1.41^{\circ} \times 1.39^{\circ}$ & $\mathrm{Atm}^{1}, \mathrm{Aero}^{2}, \mathrm{LS}^{4}, \mathrm{O}^{5}, \mathrm{SI}^{7}$ \\
\hline MIROC-ESM & $2.81^{\circ} \times 1.77^{\circ}$ & $\mathrm{Atm}^{1}, \mathrm{Aero}^{2}, \mathrm{LS}^{4}, \mathrm{O}^{5}, \mathrm{OB}^{6}, \mathrm{SI}^{7}$ \\
\hline $\begin{array}{l}\text { MIROC-ESM- } \\
\text { CHEM }\end{array}$ & $2.81^{\circ} \times 1.77^{\circ}$ & $\begin{array}{l}\mathrm{Atm}^{1}, \mathrm{Aero}^{2}, \mathrm{AtmCH}^{3}, \\
\mathrm{LS}^{4}, \mathrm{O}^{5}, \mathrm{OB}^{6}, \mathrm{SI}^{7}\end{array}$ \\
\hline HadGEM2-ES & $1.875^{\circ} \times 1.25^{\circ}$ & $\begin{array}{l}\mathrm{Atm}^{1}, \mathrm{Aero}^{2}, \mathrm{AtmCH}^{3}, \\
\mathrm{LS}^{4}, \mathrm{O}^{5}, \mathrm{OB}^{6}, \mathrm{SI}^{7}\end{array}$ \\
\hline MRI-CGCM3 & $1.125^{\circ} \times 1.125^{\circ}$ & $\mathrm{Atm}^{1}, \mathrm{Aero}^{2}, \mathrm{LS}^{4}, \mathrm{O}^{5}, \mathrm{SI}^{7}$ \\
\hline GISS-E2-R & $2.5^{\circ} \times 2.0^{\circ}$ & $\mathrm{Atm}^{1}, \mathrm{Aero}^{2}, \mathrm{AtmCH}^{3}$, \\
\hline
\end{tabular}


Space Studies /NASA GISS

\begin{tabular}{|c|c|c|c|}
\hline & GISS-E2-H & $2.5^{\circ} \times 2.0^{\circ}$ & $\begin{array}{l}\operatorname{Atm}^{1}, \mathrm{Aero}^{2}, \mathrm{AtmCH}^{3} \\
\mathrm{LS}^{4}, \mathrm{O}^{5}, \mathrm{SI}^{7}\end{array}$ \\
\hline $\begin{array}{l}\text { National Center for Atmospheric } \\
\text { Research/NCAR }\end{array}$ & CCSM4 & $1.25^{\circ} \mathrm{v} 0.9^{\circ}$ & $\mathrm{Atm}^{1}, \mathrm{Aero}^{2}, \mathrm{LS}^{4}, \mathrm{O}^{5}, \mathrm{SI}^{7}$ \\
\hline $\begin{array}{l}\text { National Institute of } \\
\text { Meteorological Research/Korea } \\
\text { Meteorological Administration } \\
\text { /NIMR/KMA }\end{array}$ & HadGEM2-AO & $1.875^{\circ} \times 1.25^{\circ}$ & $\mathrm{Atm}^{1}, \mathrm{Aero}^{2}, \mathrm{LS}^{4}, \mathrm{O}^{5}, \mathrm{SI}^{7}$ \\
\hline \multirow{3}{*}{$\begin{array}{l}\text { NOAA Geophysical Fluid } \\
\text { Dynamics Laboratory/NOAA } \\
\text { GFDL }\end{array}$} & GFDL-CM3 & $2.5^{\circ} \times 2.0^{\circ}$ & $\begin{array}{l}\mathrm{Atm}^{1}, \mathrm{Aero}^{2}, \mathrm{AtmCH}^{3} \text {, } \\
\mathrm{LS}^{4}, \mathrm{O}^{5}, \mathrm{SI}^{7}\end{array}$ \\
\hline & GFDL-ESM2G & $2.5^{\circ} \times 2.0^{\circ}$ & $\begin{array}{l}\mathrm{Atm}^{1}, \mathrm{Aero}^{2} \\
\mathrm{LS}^{4}, \mathrm{O}^{5}, \mathrm{OB}^{6}, \mathrm{SI}^{7}\end{array}$ \\
\hline & GFDL-ESM2M & $2.5^{\circ} \times 2.0^{\circ}$ & $\begin{array}{l}\mathrm{Atm}^{1}, \mathrm{Aero}^{2} \\
\mathrm{LS}^{4}, \mathrm{O}^{5}, \mathrm{OB}^{6}, \mathrm{SI}^{7}\end{array}$ \\
\hline $\begin{array}{l}\text { National Science Foundation, } \\
\text { Department of Energy, National } \\
\text { Center for Atmospheric Research } \\
\text { (NSF-DOE-NCAR) }\end{array}$ & CESM1(CAM5) & $1.25^{\circ} \times 0.9^{\circ}$ & $\mathrm{Atm}^{1}, \mathrm{Aero}^{2}, \mathrm{LS}^{4}, \mathrm{O}^{5}, \mathrm{SI}^{7}$ \\
\hline
\end{tabular}


Table 3.Statistical criteria for SWAT model calibration and validation for nine USGS gauging stations within the Saginaw Bay watershed.

\begin{tabular}{|c|c|c|c|}
\hline $\begin{array}{l}\text { USGS } \\
\text { Station }\end{array}$ & $\begin{array}{c}\text { NSE* }^{*} \\
\text { (performance rating) }\end{array}$ & $\begin{array}{c}\mathrm{RSR}^{* *} \\
\text { (performance rating) }\end{array}$ & $\begin{array}{c}\text { PBIAS*** } \\
\text { (performance rating) }\end{array}$ \\
\hline 04144500 & $\begin{array}{c}0.64 \\
\text { (Satisfactory) }\end{array}$ & $\begin{array}{c}0.60 \\
\text { (Satisfactory) }\end{array}$ & $\begin{array}{c}14.27 \\
(\text { Good })\end{array}$ \\
\hline 04148140 & $\begin{array}{c}0.54 \\
\text { (Satisfactory) }\end{array}$ & $\begin{array}{c}0.68 \\
\text { (Satisfactory) }\end{array}$ & $\begin{array}{c}-9.68 \\
\text { (Very Good) }\end{array}$ \\
\hline 04148500 & $\begin{array}{c}0.71 \\
\text { (Good) }\end{array}$ & $\begin{array}{c}0.54 \\
\text { (Good) }\end{array}$ & $\begin{array}{c}16.34 \\
\text { (Satisfactory) }\end{array}$ \\
\hline 04147500 & $\begin{array}{c}0.63 \\
\text { (Satisfactory) }\end{array}$ & $\begin{array}{c}0.61 \\
\text { (Satisfactory) }\end{array}$ & $\begin{array}{c}-1.53 \\
\text { (Very Good) }\end{array}$ \\
\hline 04151500 & $\begin{array}{c}0.64 \\
\text { (Satisfactory) }\end{array}$ & $\begin{array}{c}0.60 \\
\text { (Satisfactory) }\end{array}$ & $\begin{array}{c}13.77 \\
\text { (Good) }\end{array}$ \\
\hline 04154000 & $\begin{array}{c}0.54 \\
\text { (Satisfactory) }\end{array}$ & $\begin{array}{c}0.68 \\
\text { (Satisfactory) }\end{array}$ & $\begin{array}{c}9.65 \\
\text { (Very Good) }\end{array}$ \\
\hline 04155500 & $\begin{array}{c}0.61 \\
\text { (Satisfactory) }\end{array}$ & $\begin{array}{c}0.63 \\
\text { (Satisfactory) }\end{array}$ & $\begin{array}{c}9.84 \\
\text { (Very Good) }\end{array}$ \\
\hline 04156000 & $\begin{array}{c}0.73 \\
\text { (Good) }\end{array}$ & $\begin{array}{c}0.52 \\
\text { (Good) }\end{array}$ & $\begin{array}{c}6.44 \\
\text { (Very Good) }\end{array}$ \\
\hline 04157000 & $\begin{array}{c}0.80 \\
\text { (Very Good) }\end{array}$ & $\begin{array}{c}0.45 \\
\text { (Very Good) }\end{array}$ & $\begin{array}{c}10.90 \\
\text { (Good) }\end{array}$ \\
\hline
\end{tabular}

* Nash-Sutcliffe model efficiency coefficient,

** Root-mean-squared error-observations standard deviation ratio, *** Percent bias. 
Table 4. Top 15 ranked variables

\begin{tabular}{cl}
\hline Ranking & \\
\hline 1 & Average flow rate from 1 month prior to the month of interest \\
2 & Average flow rate from 2 months prior to the month of interest \\
3 & Average flow rate from 24 months prior to the month of interest \\
4 & Average flow rate from 12 months prior to the month of interest \\
5 & Average flow rate from 13 months prior to the month of interest \\
6 & Average flow rate from 11 months prior to the month of interest \\
7 & Average flow rate from 3 months prior to the month of interest \\
8 & Average flow rate from 23 months prior to the month of interest \\
9 & Average flow rate from 14 months prior to the month of interest \\
10 & Average flow rate from 10 months prior to the month of interest \\
11 & Average flow rate from 4 months prior to the month of interest \\
12 & Average flow rate from 22 months prior to the month of interest \\
13 & Average flow rate from 15 months prior to the month of interest \\
14 & Average flow rate from 9 months prior to the month of interest \\
15 & Average flow rate from 5 months prior to the month of interest \\
\hline
\end{tabular}


Table 5. Current Drought Severity Model performances

\begin{tabular}{|c|c|c|c|c|c|c|c|c|c|}
\hline \multirow{3}{*}{ Model } & \multirow{3}{*}{$\begin{array}{c}\text { Number of } \\
\text { Variables }\end{array}$} & \multicolumn{8}{|c|}{$R^{2}$} \\
\hline & & \multicolumn{8}{|c|}{ Stream order } \\
\hline & & (All) & (1) & (2) & (3) & (4) & (5) & (6) & (7) \\
\hline First & 5 & 0.86 & 0.74 & 0.71 & 0.72 & 0.76 & 0.81 & 0.64 & 0.74 \\
\hline Second & 10 & 0.86 & 0.74 & 0.72 & 0.72 & 0.76 & 0.81 & 0.66 & 0.76 \\
\hline Third & 15 & 0.86 & 0.74 & 0.72 & 0.72 & 0.76 & 0.81 & 0.66 & 0.76 \\
\hline
\end{tabular}


Table 6. Future Drought Severity Model performances

\begin{tabular}{lcccccccccc}
\hline & & \multicolumn{7}{c}{$R^{2}$} \\
Model & $\begin{array}{c}\text { Number of } \\
\text { Variables }\end{array}$ & & \multicolumn{7}{c}{ Stream order } \\
\cline { 3 - 10 } & & $($ All $)$ & $(1)$ & $(2)$ & $(3)$ & $(4)$ & $(5)$ & $(6)$ & $(7)$ \\
\hline Fourth & 34 & 0.85 & 0.71 & 0.67 & 0.67 & 0.71 & 0.76 & 0.58 & 0.69 \\
Fifth & 16 & 0.85 & 0.69 & 0.66 & 0.66 & 0.69 & 0.74 & 0.56 & 0.67 \\
Sixth & 7 & 0.76 & 0.53 & 0.46 & 0.46 & 0.50 & 0.61 & 0.32 & 0.49 \\
\hline
\end{tabular}


Table 7. Confusion matrix for drought zones: First model

\begin{tabular}{|c|c|c|c|c|c|c|}
\hline \multirow{2}{*}{\multicolumn{2}{|c|}{$\begin{array}{l}\text { Drought } \\
\text { Zone }\end{array}$}} & \multicolumn{4}{|c|}{ Predicted } & \multirow[b]{2}{*}{ Sensitivity } \\
\hline & & A & B & $\mathrm{C}$ & $\mathrm{D}$ & \\
\hline \multirow{4}{*}{ 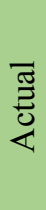 } & $\mathrm{A}$ & $3,410,732$ & 99,090 & 82,247 & 484,990 & $84 \%$ \\
\hline & $\mathrm{B}$ & 89,968 & 85,271 & 10,230 & 87,386 & $31 \%$ \\
\hline & $\mathrm{C}$ & 66,450 & 8,292 & 9,082 & 66,863 & $6 \%$ \\
\hline & $\mathrm{D}$ & 530,891 & 78,431 & 57,450 & $1,272,877$ & $66 \%$ \\
\hline \multicolumn{2}{|c|}{ Precision } & $83 \%$ & $31 \%$ & $6 \%$ & $67 \%$ & Accuracy $=74 \%$ \\
\hline
\end{tabular}


Table 8. Confusion matrix for drought zones: Fourth Model

\begin{tabular}{|c|c|c|c|c|c|c|}
\hline & \multirow[b]{2}{*}{$\begin{array}{l}\text { Drought } \\
\text { Zone }\end{array}$} & \multicolumn{4}{|c|}{ Predicted } & \multirow[b]{2}{*}{ Sensitivity } \\
\hline & & A & B & $\mathrm{C}$ & D & \\
\hline \multirow{5}{*}{ 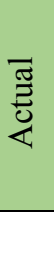 } & A & $3,400,622$ & 81,426 & 66,065 & 503,081 & $84 \%$ \\
\hline & B & 107,300 & 82,647 & 6,523 & 75,077 & $30 \%$ \\
\hline & $\mathrm{C}$ & 83,139 & 6,350 & 6,304 & 54,046 & $4 \%$ \\
\hline & $\mathrm{D}$ & 756,301 & 85,320 & 52,635 & $1,026,748$ & $53 \%$ \\
\hline & Precision & $78 \%$ & $32 \%$ & $5 \%$ & $62 \%$ & Accuracy $=71 \%$ \\
\hline
\end{tabular}


Table 9. Overall first model performance against 47 future climate scenarios

\begin{tabular}{|c|c|c|c|}
\hline \multirow{2}{*}{$\begin{array}{l}\text { The Best Drought } \\
\text { Model Performance }\end{array}$} & \multicolumn{2}{|c|}{$\begin{array}{c}\log _{10} \text { median flow (median flow) in } \\
\text { cms }^{*}\end{array}$} & \multirow{2}{*}{$\begin{array}{c}\text { No-drought/Drought } \\
\text { Accuracy }\end{array}$} \\
\hline & RMSE & $R^{2}$ & \\
\hline Minimum & $0.4940(3.4312)$ & $0.8621(0.4773)$ & 0.7689 \\
\hline Maximum & $0.5407(5.9447)$ & $0.8861(0.6596)$ & 0.8470 \\
\hline Mean & $0.5153(4.5691)$ & $0.8745(0.6058)$ & 0.8053 \\
\hline Standard deviations & $0.0097(0.6271)$ & $0.0048(0.0398)$ & 0.0187 \\
\hline
\end{tabular}


Figure 1

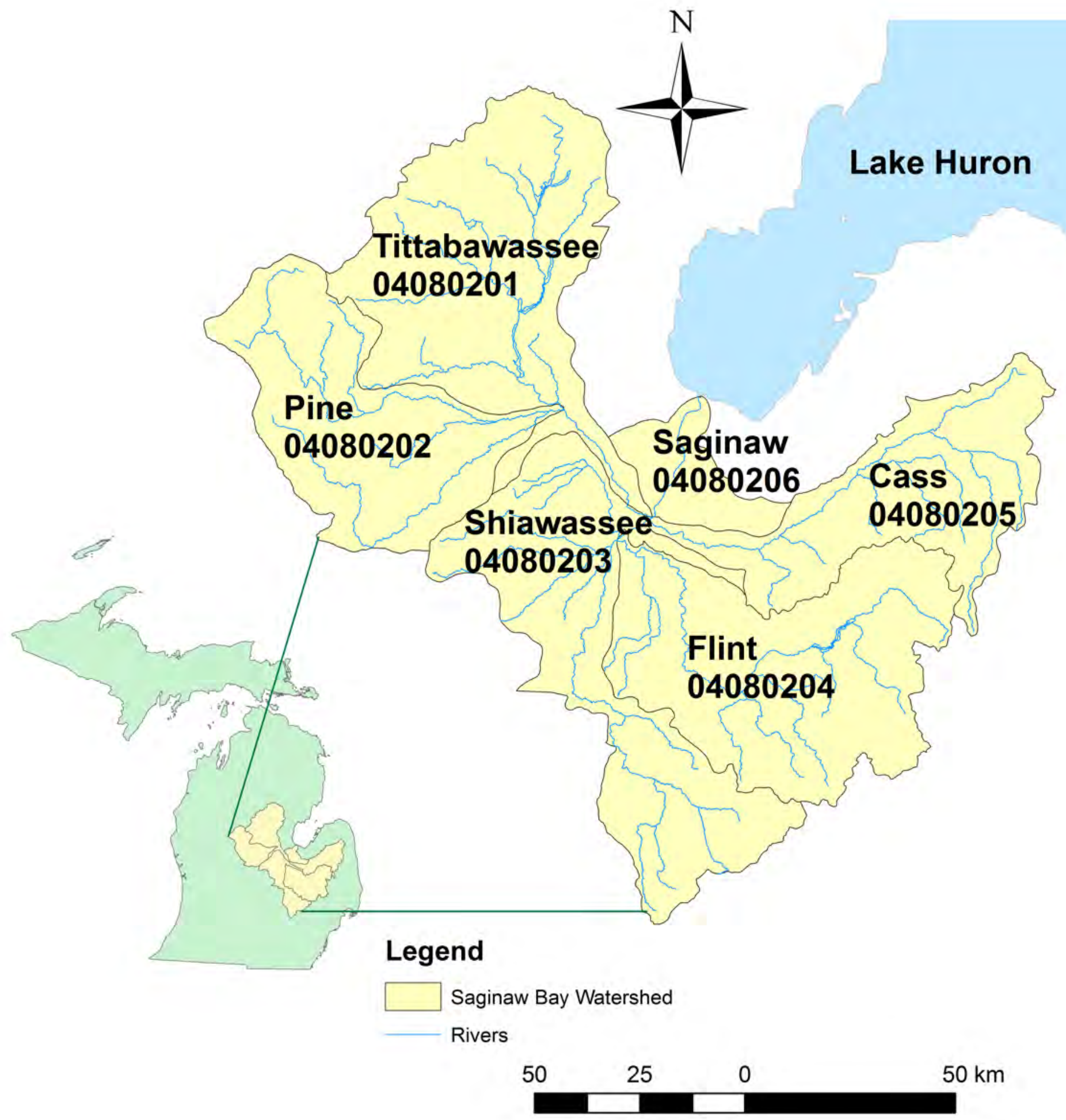




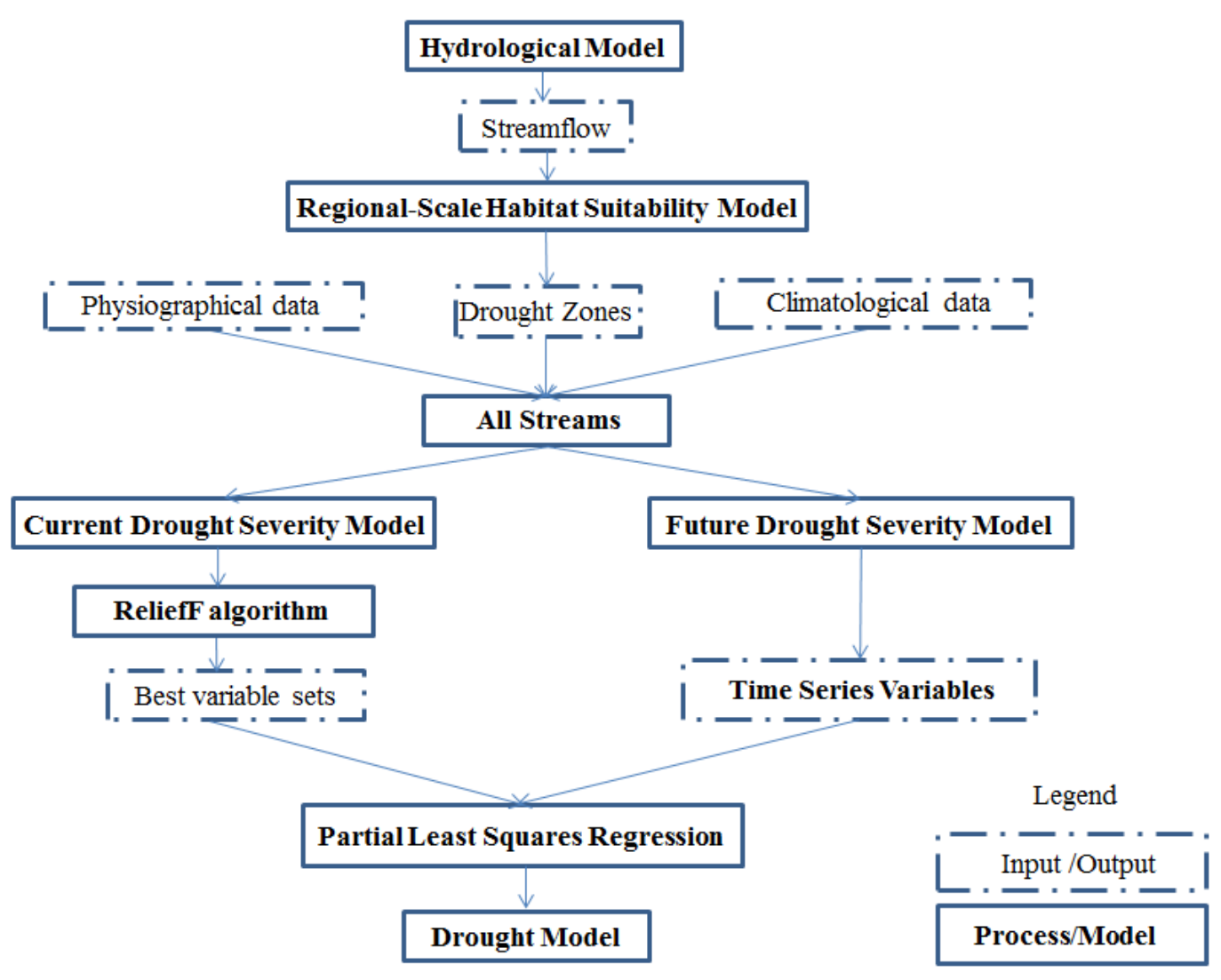


Figure 3

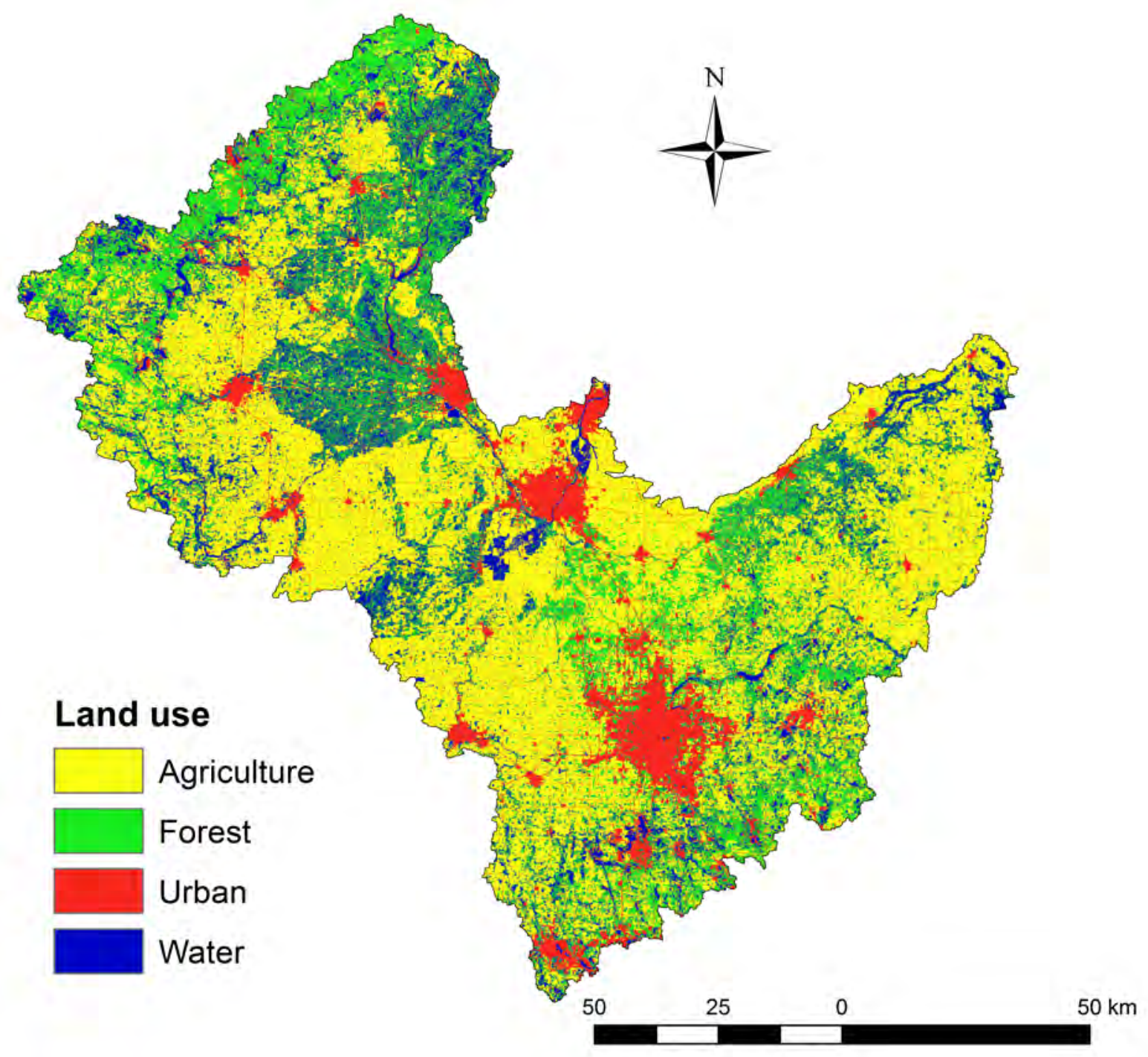


Figure 4

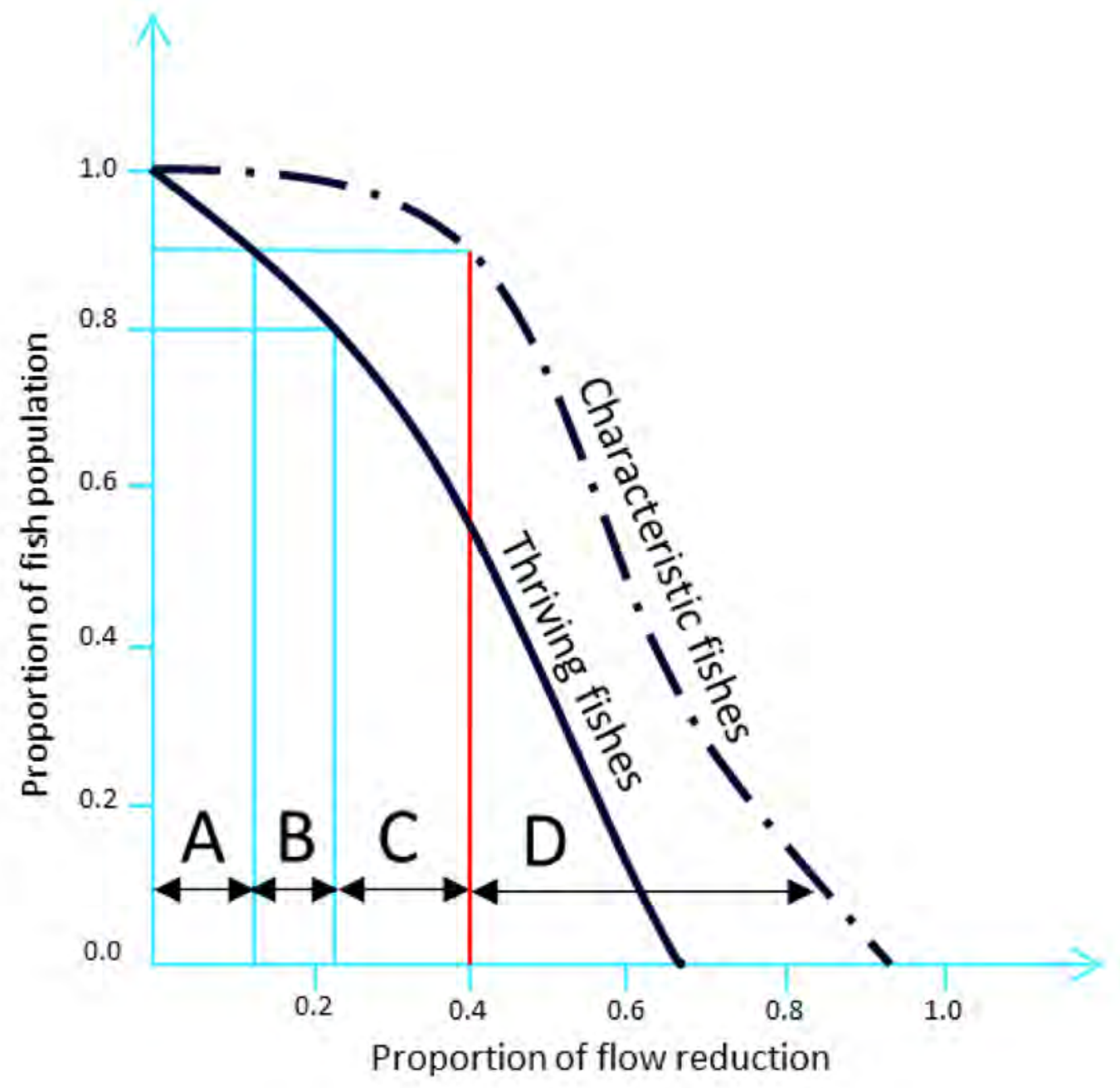


Figure 5

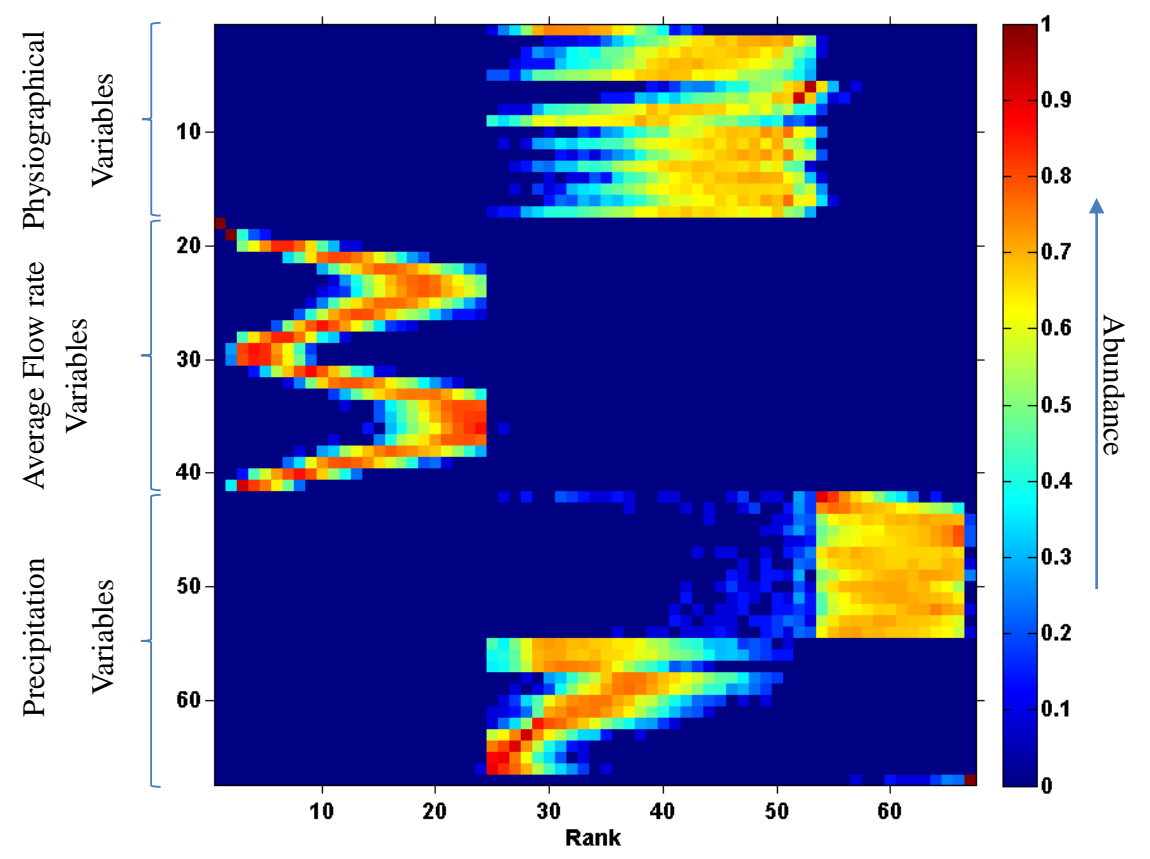


Figure 6

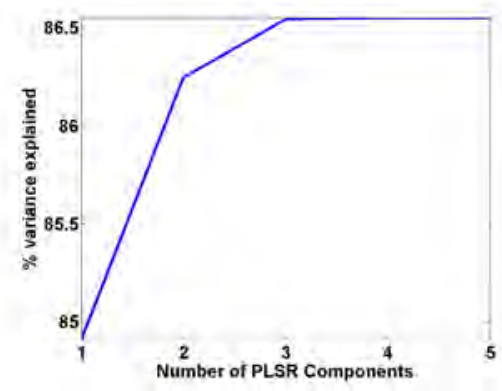

(a)

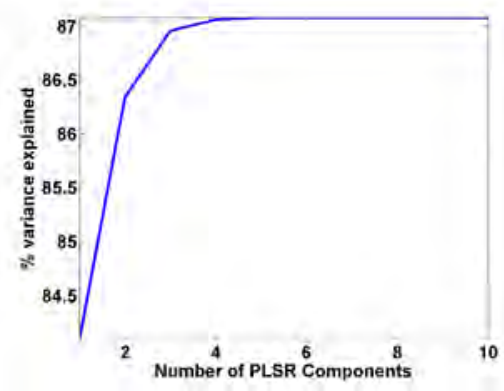

(b)

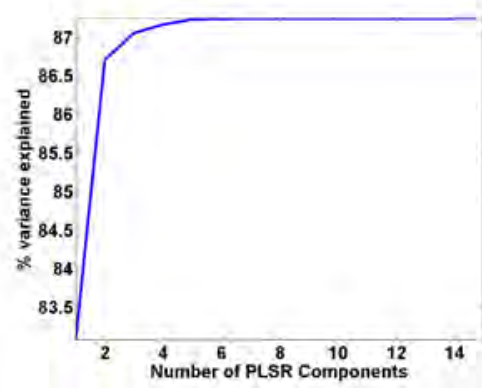

(c) 
Figure 7

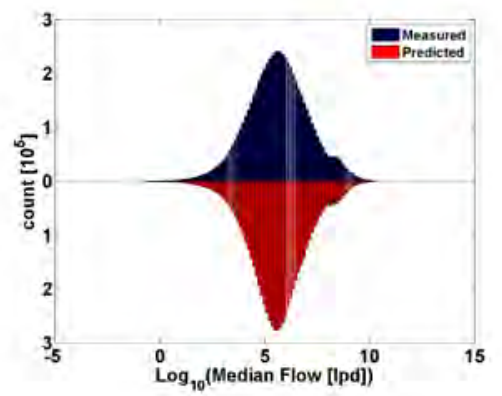

(a)

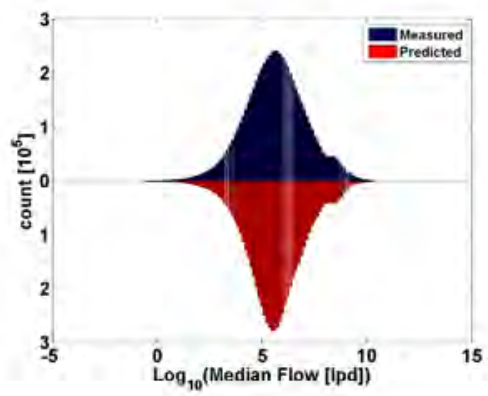

(b)

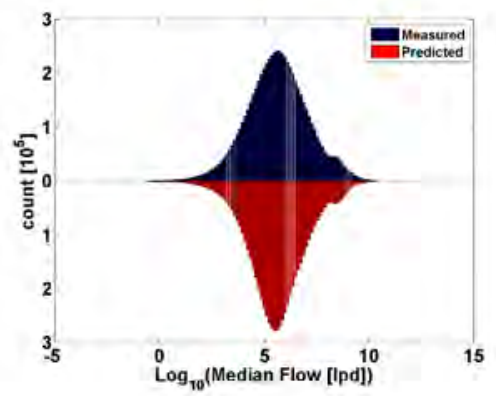

(c) 


\section{Figure 8}

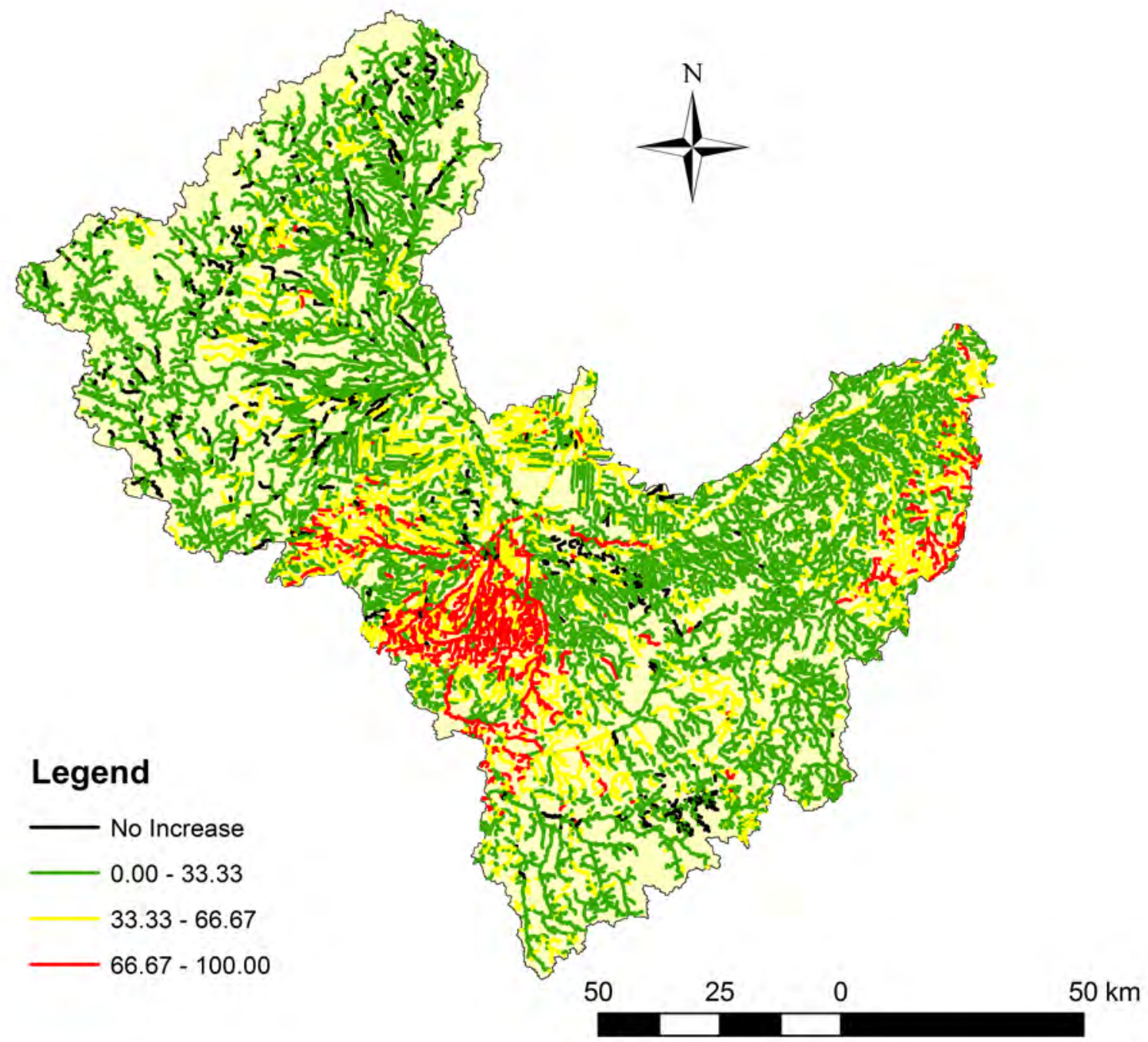




\section{Figure 9}

(a)

Legend
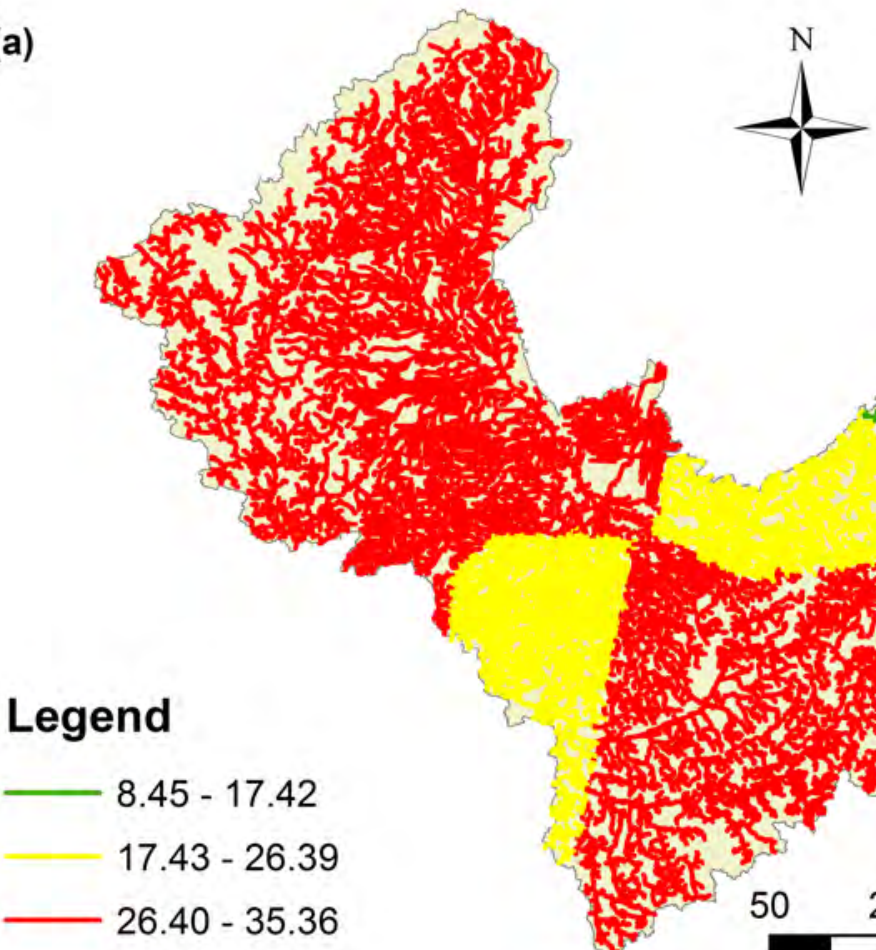

$2 \mathrm{~s}$.

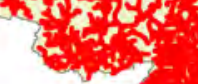

$-\frac{1}{8}$
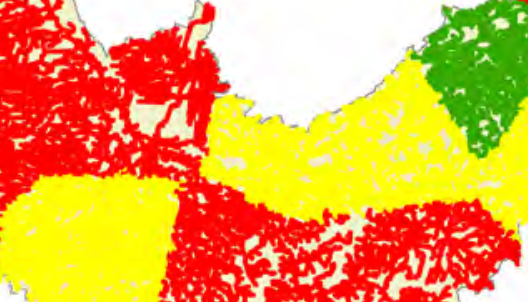

(b)
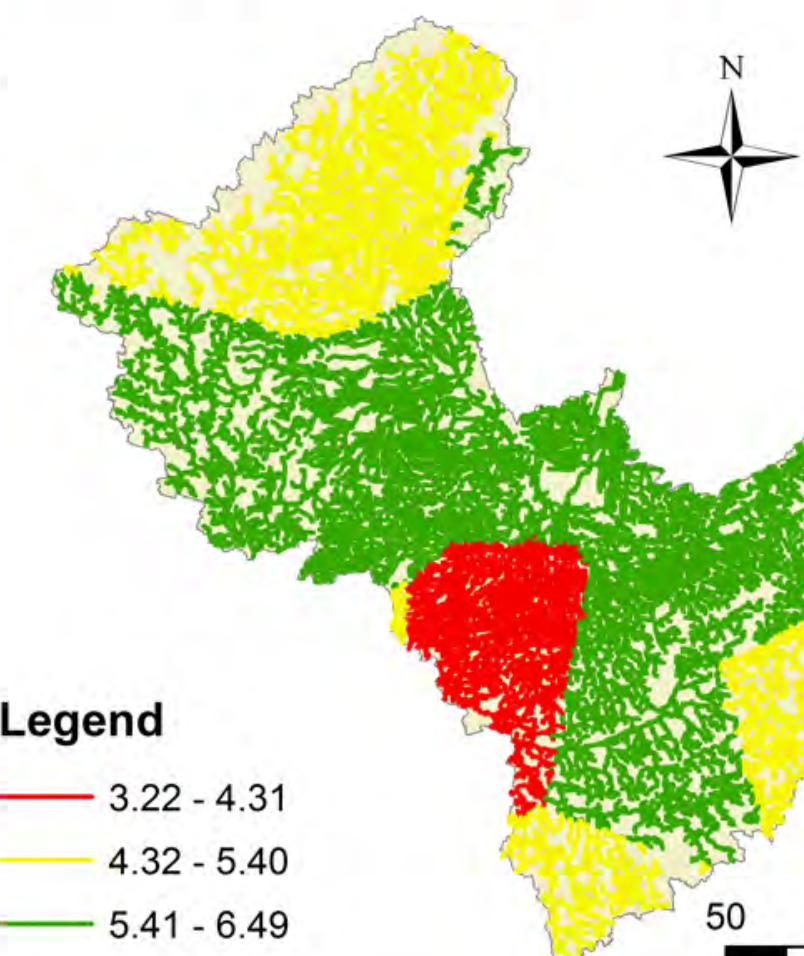